\title{
Athafnafólk í opinberri stefnumótun á óvissutímum: Hvernig hugmyndin um notendastýrða persónulega ađstoð varð að veruleika á Íslandi
}

Sigurbjörg Sigurgeirsdóttir, dósent í opinberri stjórnsýslu við Stjórnmálafræđideild Háskóla Íslands.

\section{Útdráttur}

Dessi rannsókn leitast við að útskýra tímamótaákvörðun ípjónustu við fatlað fólk á Íslandi. Opinber stefnumótun hefur löngum einkennst af hægfara breytingum, sem gerast í smáum skrefum. Stundum bregður pó svo við að meiriháttar breytingar verða og stefnumál, sem verið hefur baráttumál hagsmunahópa um margra ára skeið, ná fram að ganga. Dagskrárkenningar leitast við að útskýra meiriháttar stefnubreytingar með pví m.a. að beina athyglinni að pví hvernig og hvers vegna tiltekin málefni koma til kasta stjórnvalda á hverju tíma. Bandaríski stjórnmálafræðingurinn, John W. Kingdon, setti fyrst fram kenningu sína um straumana prjá og glugga tækifæranna fyrir rúmum 30 árum. Nýlegar rannsóknir evrópskra stjórnmálafræðinga halda pví nú fram að nálgun Kingdons geti varpað ljósi á pað hvernig pað pólitíska kerfi sem stefnumótunin fer fram í virkar og hvernig hegðun og aðferðir pátttakenda í ferlinu hafa áhrif. Í pessari eigindlegu rannsókn er skoðað hvernig hugmyndin um notendastýrða persónulega aðstoð (NPA) varð að veruleika á Îslandi. Rannsóknin byggir á fyrirliggjandi gögnum og viðtölum við lykilfólk um pá framvindu mála sem leiddi til ákvörðunar um að innleiða NPA hér á landi. Rannsóknin lýsir pví hvernig og undir hvaða kringumstæðum NPA komst á dagskrá stjórnvalda. Niðurstöðurnar sýna hvernig breytingar á verkaskiptingu milli ríkis og sveitarfélaga gáfu tækifæri 
fyrir nýja hugmyndafræði sem nýttist bæði notendum, viðskiptahagsmunum og pólitískum hagsmunum. Niðurstöðurnar benda til pess að par hafi ekki aðeins verið réttur maður á réttum stað á réttum tíma, heldur varpa pær fræðilegu ljósi á pað hvað einkennir athafnafólk í opinberri stefnumótun og hvernig og hvers vegna pað skiptir máli á óvissutímum í stjórnmálum.

Efnisorđ: Opinber stefnumótun; skipulagsbreytingar; hagsmunahópar; athafnafólk og pólitísk tækifæri.

\title{
Policy entrepreneurs in times of uncertainty: How the idea of userdriven personal assistance came to fruition in Iceland
}

\begin{abstract}
This research seeks to explain a landmark change in the provision of public services for people with disabilities in Iceland. Public policy has for long been characterized by incremental changes. Every now and then, major policy changes take place and longstanding policy objectives pushed by interest groups come through. Agenda-setting theories seek to explain major policy changes by focusing on how and why a policy issue gets on governments' agenda at a given point in time. The American political scientist, John W. Kingdon, presented his theory of three streams and the window of opportunity some 30 years ago. European scientists maintain in their recent research that Kingdon's approach is helpful in shedding light on how the political system in which public policy-making takes place operates and how behaviour and strategies of those participating in the process influence the outcome. This qualitative research examines how the idea about user-driven personal assistance came to fruition in Iceland. The study is based on existing data and interviews with key people involved in the policy development leading to the decision to implement the programme of user-driven personal assistance. The research describes how and why this idea reached the government agenda and came to be implemented by Icelandic authorities. The conclusions show how the process of decentralisation opened opportunities for a new ideology which benefitted service users, and business as well as political interests. The conclusions indicate that not only was there a right man at the right place at the right time, but it provides theoretical explanations about what characterises policy entrepreneurs and how and why their activities matter in times of uncertainty.
\end{abstract}

Keywords: public policy; organisational change; interest groups: policy entrepreneurs and political opportunity. 


\section{Inngangur}

Stundum er sagt að réttur maður á réttum stað á réttum tíma sé allt sem parf til að mikilvæg og langpráð markmið nái fram að ganga. Hvað pað er nákvæmlega sem er rétt við manninn, staðinn eða stundina fylgir ekki alltaf sögunni, - né hvort petta prennt sé á einhvern hátt háð eða óháð hvert öðru. Pegar mikilvæg og langpráð markmið í opinberri stefnumótun hafa náðst pá vaknar sú klassíska spurning hvort pað megi pakka pað skipulaginu eða eiginleikum pess einstaklings eða einstaklinga sem par komu að málum. Til að reyna að átta sig á pessu pá hefur félagsvísindafólk haft tilhneigingu til að leita skýringa í skipulagsbreytingum, meðan fjölmiðlafólk hefur aftur meiri tilhneigingu til að leggja áhersluna á petta með rétta manninn á rétta staðnum á rétta tímanum. Petta segir Kingdon $(1995,182)$ um leið og hann heldur pví fram að báðir hafi í raun rétt fyrir sér.

Bandaríski stjórnmálafræðingurinn John W. Kingdon, sem kom fram með hugmyndina um ,glugga tækifæranna“, heldur pví fram að slíkir gluggar opnist vegna aðstæðna sem hafi skapast óháð viðkomandi einstakling. Aftur á móti geti viðkomandi verið í aðstöðu til að nýta sér tækifærið sem par gefist. Sé pannig litið á meiriháttar breytingar er verið að segja að einstaklingar eru jú mikilvægir, en um leið pá geti pessi skilningur sagt okkur hvers vegna og hvenær einstaklingar eru mikilvægir. Með öðrum orðum, pessi kenning Kingdons gerir ráð fyrir pví að tilviljanir geti ráðið miklu. Kanadíski stjórnmálafræðingurinn Tuohy myndi kalla pessa skýringu Kingdons „rökrétta röð tilviljana“ (e. accidental logics) sem er hugtak sem lýsir samspili milli röð tilviljana, rökhugsunar og tíma (Tuohy 1999). Skilja ber yfirskrift pessarar greinar einmitt með petta samspil einstaklinga, tilviljana og tímasetninga í huga. Yfirskriftin segir pannig ekkert um kosti og galla hugmyndarinnar um notendastýrða persónulega aðstoð (NPA). Yfirskriftin gefur aftur á móti tilkynna pað sem einkennir stefnumótunarferlið sem leiddi til pess að hugmyndin var innleidd hér á landi, sé petta ferli skoðað í fræðilegu ljósi.

Kjarninn í viðfangsefni pessarar rannsóknar snýst pannig ekki um pað verkefni sem NPA á að leysa í lífi fatlaðs fólks. Viðfangsefni rannsóknarinnar er fyrst og fremst greining á próun NPA hugmyndarinnar sem stefnumáls er miðar að pví að koma til móts við parfir og réttindi fatlaðs fólks. Par er athyglinni ekki hvað síst beint að peim páttum opinberrar stefnumótunar sem einna helst eru taldir marka páttaskil í próun opinberra stefnumála og leiða til meiriháttar stefnubreytinga. Opinber stefnumótun miðar að pví að leysa tiltekin vandamál sem almenn sátt ríkir um að eigi að leysa með aðgerðum stjórnvalda (Kingdon 1995; Knill og Tosun 2012).

Eitt er að almenn sátt ríki um að vandamál sé samfélagslegt viðfangsefni og réttlæti aðkomu stjórnvalda, annað er að koma sér saman um lausnina. Hvaða lausn verður fyrir valinu, hvernig hún er útfærð og hvers vegna er hluti af pólitísku ferli. Í pví pólitíska ferli getur ráðið úrslitum hverjir eru par pátttakendur, hvers vegna peir taka pátt í pessu ferli, hvað einkennir pessa pátttakendur og hvernig tengjast peir peim lausnum sem eru til umræðu. NPA komst á dagskrá íslenskra stjórnmála í aðdraganda að yfirfærslu á málefnum fatlaðs fólks frá ríki til sveitarfélaga árin 2009-2010. Nokkrar atrennur höfðu verið gerðar að yfirfærslu málaflokksins til sveitarfélaganna. Đær tilraunir höfðu hins vegar runnið út í sandinn einkum vegna ágreinings sem rekja mátti til reynslunnar af 
flutningi grunnskólans til sveitarfélaganna á tíunda áratugnum og snýr að fjármögnun og tekjustofnum.

Í pessari rannsókn verður rakin próun NPA hugmyndarinnar hér á landi og pær aðgerðir sem miðuðu að pví að ná athygli stjórnmálanna á fyrsta áratug pessarar aldar. Með pví að rekja próun NPA hugmyndarinnar er verið að lýsa próun á peirri útfærslu sem hugmyndin fékk í túlkunum og meðförum peirra hópa sem hvað best pekktu til peirra verkefna sem hugmyndinni var ætlað að leysa. Pessir hópar voru notendur og hagsmunasamtök peirra, fagfólk og sérfræðingar innan stjórnsýslunnar. Pá verður í stuttu máli rakinn sá ferill innan stjórnsýslunnar sem síðan leiddi til setningar laga nr.152/2010 um málefni fatlaðra og pví lýst hvernig hugmyndin um NPA er sett fram í peim lögum. Með pví að rekja stefnumörkun stjórnvalda eins og hún birtist í tímans rás með setningu laga, reglugerða og öðrum opinberum ákvörðunum er verið að lýsa yfirlýstum áformum stjórnvalda sem hafa tekið málefni fatlaðs fólks á dagskrá hverju sinni. Áður en hugmynd verður að veruleika parf hún að standast bæði tæknileg og hugmyndafræðileg próf til að fá pann hljómgrunn sem parf til að hún geti talist raunhæf sem opinbert stefnumál. pannig brúast bilið milli hugmyndar og stefnu, ef tekið er mið af rannsóknum Kingdons (1995).

Rannsóknin sýnir á hvern hátt pátttakendur í stefnumarkandi breytingum skipta máli við próun hugmynda og útfærslu einstakra stefnumála, og hvaða vísbendingar pað getur gefið fyrir framvindu málsins pegar að innleiðingu pess kemur.

Hér verður í fyrstu útskýrð aðferðarfræði rannsóknarinnar og síðan farið nánar yfir fræðilega staðsetningu hennar. Đar eru helstu hugtök og beiting peirra útskýrð. Đá verða rakin nokkur lykilatriði úr próun og framvindu NPA hugmyndarinnar hér á landi. Pessi atriði eru rakin í tímaröð til að ná fram pví próunarferli hugmynda sem oftast er undanfari ákvörðunar. Petta ferli lýsir próun hugmyndarinnar í víðu samfélagslegu samhengi og pví hvernig hugmyndin verður að stefnmáli í opinberri stefnumótun. Dá verður rakinn sögulegur aðdragandi að sampykkt laga nr. 152/2010 um málefni fatlaðra og lýst skipan verkefnisstjórnar um innleiðingu NPA verkefnisins í apríl 2011 og helstu verkefnum hennar. Að lokum verða helstu staðreyndir pessarar framvindu ræddar í fræðilegu ljósi og pess freistað í niðurstöðunum að draga fram helstu vísbendingar um framhaldið, byggt á peirri greiningu sem umræðan gefur tilefni til.

\section{Rannsóknin og rannsóknarađferđir}

pessi rannsókn beinist að meiriháttar breytingum par sem opinber stefnumótun leiðir til pess að langpráð markmið verður að veruleika. Petta er tilviksrannsókn í opinberri stefnumótun (Yin 1994) par sem meginmarkmið rannsóknarinnar er að varpa ljósi á pað hvernig stjórnmálakerfið og opinber stjórnsýsla á Íslandi virkar pegar opinber stefna er mótuð. Ákvörðunin um að innleiða NPA á Íslandi er, í rannsókninni, tekin sem dæmi um meiriháttar breytingar á vettvangi hins opinbera, enda markar sú ákvörðun tímamót í pjónustu við fatlað fólk hér á landi. Í rannsókninni er leitast við að draga fram helstu einkenni stefnumótunarferlisins með pví að skoða gögn rannsóknarinnar í fræðilegu ljósi. Í pessum tilgangi hefur verið safnað rituðum heimildum og aflað upplýsinga með 
viðtölum við lykilpátttakendur sem með einum eða öðrum hætti komu að ákvörðun og innleiðingu hugmyndarinnar um NPA á Íslandi.

Gagnaöflun hófst haustið 2013. Rituðum heimildum um undirbúning að ákvörðuninni um að innleiða NPA á Íslandi var safnað og pær rýndar. Eftir pá rýni voru tekin 6 ítarleg viðtöl við sérstaklega valið lykilfólk í pví ferli sem átti sér stað á tímabilinu 2009-2011. Viðtölin voru tekin upp. Fyrstu niðurstöður voru kynntar á ráðstefnu um NPA sem haldin var á vegum Samtaka félagsmálastjóra á Íslandi og Sambands íslenskra sveitarfélaga í október 2013. Í framhaldi af peirri kynningu var haldið áfram að safna og skoða ritaðar heimildir. Viðtölin voru síðan skrifuð upp og kóðuð. Í júní 2016 voru fyrstu drög að pessari grein kynnt í málstofu á ráostefnu Félags íslenskra stjórnmálafræðinga á Íslandi. Í framhaldi af peirri ráðstefnu voru tekin 4 viðbótarviðtöl til að sannreyna gögnin og greiningu peirra. Tveir úr hópi viðmælenda lásu yfir handritið, leiðréttu staðreyndavillur og komu með ábendingar um viðbótargögn.

Rannsóknargögnin voru skoðuð, skráð og sett fram með lýsingu á framvindu hugmyndarinnar um NPA í tímaröð. Stuðst var við pá aðferð að rekja ferli (e. process tracing) með pví að gefa vandlega lýsingu á rás atburða og ákvarðana í réttri tímaröð (Bennett 2008; Collier 2011). Pannig er búin til frásögn (e. narrative), sem er saga málsins (e. case history). Innan pessarar sögu er ákveðið ferli afmarkað og skilgreint út frá tiltekinni niðurstöðu á tilteknum tíma (e. policy outcome) og ákveðnu upphafi sem stendur í orsakasambandi við niðurstöðuna. Pessi hluti ferlisins er hin eiginlega tilviksathugun (e. case study). Í pessari rannsókn er pað ferlið frá pví í mars 2009 til loka ársins 2011. Skoðun höfundar beinist að pví að greina tengsl atburða við pað sem á eftir kemur og útskýra hvernig pað tengist lokaniðurstöðunni (e. processual analysis) (Pettigrew 1997). Atburðir fyrir (e. prior events) og eftir petta tímabil tilviksathugunarinnar (e. later events) eru hluti af pví samhengi sem fyrst og fremst gagnast rannsókninni sem skýringarpæettir, en eru ekki viðfangsefni hinnar eiginlegu rannsóknargreiningar.

Í rannsókninni er leitast við að svara spurningum um pað hvernig og hvers vegna hugmyndin um NPA fyrir fatlað fólk komst á dagskrá og til framkvæmda hjá íslenskum stjórnvöldum árið 2011. Athyglinni er fyrst og fremst beint að aðdraganda að setningu laga nr.152/2010 með breytingum á lögum nr.59/1992 um málefni fatlaðra með síðari breytingum. Í peim aðdraganda er leitað svara sem varpað geta ljósi á pað hvernig og hvers vegna pessi hugmyndi varð að veruleika á pessum tiltekna tíma.

Til að setja spurningar rannsóknarinnar í fræðilegt samhengi er aðdragandinn skoðaður í ljósi dagskrárkenninga (e. agenda-setting theories). Pannig má draga fram fræðileg einkenni pessa stefnumótunarferlis. Pessi nálgun veitir fræðilegar skýringar á pví hvernig og hvers vegna NPA hugmyndin varð að veruleika á pessum tíma. Verður nú vikið nánar að fræðilegri staðsetningu pessarar rannsóknarinnar.

\section{Fræðileg staðsetning rannsóknar og helstu hugtök}

Bandaríski stjórnmálafræðingurinn, John W. Kingdon, er sá fræðimaður sem sett hefur fram kenningu sem markaði ákveðin tímamót í sögu rannsókna á ákvörðunum stjórnvalda (Kingdon 1995). Rannsóknir hans byggðu á peirri gagnrýni á hugmyndir skyn- 
semishyggjunnar (e. rational choice) sem birtust í skrifum peirra Herbert Simons (1947), Charles E. Lindbloms $(1959,1979)$ og rusluatunnulíkani peirra Cohen, March og Olsens (1972). Í stuttu máli beinist pessi gagnrýni að peim takmörkunum sem einkennir starfsemi mannshugans m.a. vegna takmarkaðrar getu til að vinna skipulega úr upplýsingum sem rekja má m.a. til mannlegra tilfinninga og takmarkana á minni. Petta hefur Simon kallað einu nafni "fjötraða skynsemi" (e. bounded rationality) sem leiðir til pess, að hans mati, að í stað pess að „hámarka“ árangur pá leitist menn frekar við að ná fram niðurstöðu sem er „fullnægjandi“ hverju sinni. Á pessum nótum setti Lindblom fram smáskrefakenninguna sína (e. incrementalism). Hún lýsir pví hvernig opinber stefnumótun „mjakast áfram“ (e. muddle through) með smávægilegum breytingum sem nást fram í pólitísku stefnumótunarferli með gagnkvæmri aðlögun mismunandi sjónarmiða. Ruslatunnulíkan peirra Cohen, March og Olsens er sprottið úr pessum hugmyndum og lýsir pví hvernig ákvarðanir eru teknar innan stofnana og skipulagsheilda. Par verða til fjöldinn allur af tillögum, misvel útfærðum, sem settar hafa verið til hliðar í tímans rás, en detta svo inn í umræðuna aftur, að gefnu tilefni. Petta er sá hugmyndaheimur sem kenning Kingdons verður til í, og pað er, nánar tiltekið, petta „gefna tilefni““ sem vakti forvitni Kingdons. Með rannsóknum sínum á pessu „gefna tilefni“, telur Kingdon sig hafa greint munstur sem einkennir pað ferli sem á sér stað áður en hugmynd kemst á pað stig að verða stefnumál á dagskrá ríkisstjórnar.

Rannsóknir Kingdons (1995), sem hér er byggt á, snúast um stefnumótun á vettvangi heilbrigðis- og samgöngumála í Bandaríkjunum. Par er athyglinni beint að málefnum sem komast eða komast ekki á dagskrá stjórnvalda, einkum peim páttum í ferlinu sem hafa áhrif á lokastigi stefnumótunar. Hugmyndir Kingdons, sem hann lýsir með hugtakinu ,gluggi tækifæranna“, hafa æ síðan haft mótandi áhrif á rannsóknir vestan hafs. Aftur á móti einkenndust rannsóknir stjórnmálafræðinga austan hafs til að byrja með af nokkrum efasemdum um empirískt notagildi kenningarinnar í evrópsku samhengi (Zohlnhöfer og Rub 2016, 2). Ástæðan er skiljanleg í ljósi pess að kenning Kingdons byggir á rannsóknum á opinberri stefnumótun í bandarísku stofnanaumhverfi á alríkisstiginu. Áhugi evrópskra vísindamanna á kenningu og hugmyndum Kingdons hafa hins vegar aukist hin allra síðustu ár. Pennan áhuga má m.a. rekja til rannsókna prófessors Nikolaos Zahariadis $(1995,2007)$ sem hefur um árabil beitt kenningu Kingdons við evrópskar aðstæður. Pá má ef til vill einnig rekja pennan áhuga til áhrifa annars vegar Evrópusamrunans og hins vegar til aukinnar dreifstýringar eða einkvæðingar opinberrar pjónustu á síðustu árum (Green-Pedersen og Walgrave 2014, Zohlnhöfer og Rub 2016). Í stað pess að beina sjónum sínum að hinu pólitíska kerfi, stofnunum pess eða stjórnskipaninni, pá telja Green-Pedersen og Walgrave (2014) að nálgun Kingdons geti varpað ljósi á kerfið sjálft og hvernig pað virkar hverju sinni með pví að skoða hvernig hugmynd mótast í meðförum pátttakenda sem eru í mismunandi stöðu og með mismunandi sjónarmið og hagsmuni innan sem utan kerfisins.

Kingdon hefur sjálfur aldrei gert tilraun til pess að setja kenningu sína fram sem almennt skýringalíkan. Aftur á móti pá hafa rannsóknir hans og kenningin um glugga tækifæranna og straumana prjá lagt grunninn að pví sem síðar hefur gengið undir heit- 
inu „fjölstraumalíkanið“ (e. multiple streams framework) (Zohlnhöfer og Rub 2016, $1)$.

Kenning Kingdons gerir ráð fyrir að tilviljanir geti haft áhrif í opinberri stefnumótun. Niðurstöður rannsókna hans sýna að pegar stjórnvöldum hefur tekist að ná lendingu með ákvörðun um meiriháttar stefnubreytingu pá hafi ákveðnar aðstæður, sem oft eru ófyrirséðar, purft að vera til staðar. Pessar aðstæður hefur hann kortlagt í peim tilgangi að auðvelda greiningu á pví hvað einkenni pað sem par gerist. Pannig sér hann fyrir sér að pau ferli sem ákvarða vandamál, stjórnmál og stefnumál lifi sem samfélagsleg fyrirbæri nokkuð sjálfstæðu lífi óháð hvert öðru. Við tilteknar aðstæður pegar heppilega háttar til, nær pað gangverk sem ræður gangi mála í hverjum um sig saman. Við pað skapast ákveðið tækifæri til að koma máli á dagskrá stjórnvalda. Đað er petta tækifæri sem Kingdon kallar „glugga tækifæranna“.

Í rannsóknum sínum á pví hvernig og hvers vegna sum mál komast á dagskrá stjórnvalda á tilteknum tíma en önnur ekki, hefur Kingdon komist að pví að petta megi skýra betur með pví að aðgreina tvenn mismunandi ferli og skoða pau í sitt hvoru lagi. Pessi ferli eru mismunandi að pví leyti að pátttakendur par eru mismunandi aðilar. pá gegna pessi ferli ólíku hlutverki í peirri atburðarás sem ákvarðar hvernig og hvers vegna mál koma til kasta stjórnvalda og leiða til meiriháttar breytinga. Annað ferlið kallar Kingdon einfaldlega dagskrársetningarferli, en hitt ferlið er skilgreining valkosta. Í pví fyrra eru pátttakendur stjórnmálamenn sem ráða mestu um pað hvort mál eru tekin á dagskrá eða ekki. Í pví síðara pá eru pátttakendur sérfræðingar stjórnsýslunnar eða háskóla- og rannsóknarsamfélagsins. Stjórnmálamenn eru hinir sýnilegu pátttakendur í stefnumótuninni, en sérfræðingarnir starfa að mestu utan kastljóss fjölmiðla.

Til að kortleggja svona atburðarás frekar pá sér Kingdon fyrir sér pessa prenningu, vandamál, stjórnmál og stefnumál sem prjá mismunandi „strauma“ (e. streams) par sem framvinda mála markast af ólíkum aðstæðum. Mismunandi drifkraftar kynda undir aðkomu pátttakenda innan hvers straums og einkenna pví pað gangverk sem par er að finna. Kingdon finnst gagnlegt í rannsóknarlegum tilgangi að halda pessum straumum og pví sem par gerist aðskildu til að fá sem gleggsta mynd af pví sem er að gerast í hverjum straumi. Straumana prjá kallar hann vandamálastraum, pólitískan straum og stefnustraum. Í fyrsta straumnum sér hann fyrir sér vandamálin sem geta komið fram í dagsljósið ýmist vegna óvæntra atburða í pjóðfélaginu, birtingu tölulegra upplýsinga eða einhvers konar atburða sem fá sérstaka athygli af táknrænum ástæðum. Í pólitíska straumnum koma fram ríkisstjórnarskipti, breytingar í ríkisstjórn, barátta hagsmunahópa, stemningin í samfélaginu og hugmyndafræðileg dreifing peirra flokka sem eru í pinginu hverju sinni. Í stefnustraumnum koma fram hugmyndir að lausnum og leiðum og par má finna pá pátttakendur sem Kingdon sér í pví ferli sem mótar og útfærir valkostina pegar stjórnvöld standa frammi fyrir ákvörðunum um lausnir og leiðir. Рað er í pessum hópi sem hugmyndir próast oftast yfir langan tíma og taka á sig pá mynd sem gerir pær að fýsilegum tillögum til stefnumótunar eða lausnum í opinberri stefnumótun.

Dagskrárvaldið er tvímælalaust í pólitíska straumnum og í vandamálastraumnum. Рað sem gerist í stefnustraumnum hefur ekki beinlínis vald til að koma málum á dagskrá. 
Aftur á móti getur staðan á próun hugmyndar og útfærslan á leiðum til lausna sem par má finna meðal sérfræðinga á hverjum tíma ráðið úrslitum um pað hvort og pá hvaða leiðir eru farnar pegar upp kemur vandamál sem parf að leysa. Á tilteknum tíma gerist pað, að mati Kingdons, að pátttakendur innan straumanna og pað sem par er að gerjast ná með einhverjum hætti saman og pað leiðir til pess að „gluggi tækifæranna“ opnast. Pá eru kjöraðstæður til að koma að tilteknum hugmyndum sem náð hafa pví stigi að vera útfærðar sem stefnumál og hrinda peim pannig í framkvæmd.

Hugmyndir geta, aftur á móti, ekki einar og sér komið sér á framfæri. Pað parf fólk til að tala fyrir hugmyndum og koma peim á framfæri stjórnmálanna. Gluggi tækifæranna getur opnast, en hann getur líka lokast án pess að nokkur komi auga á tækifærið sem glugginn opnaði á. Einhver parf að greina tækifærið, vera í aðstöðu til að nýta pað og láta til skarar skríða. Í rannsóknum Kingdons vaknaði athygli hans á hlutverki ,athafnafólks í opinberri stefnumótun“ (e. policy entrepreneurs). Í rannsóknum hans var slíkt athafnafólk í 15 af 23 tilvikum talið mjög eða nokkuð mikilvægt fyrir framgang mála.

Athafnafólk í opinberri stefnumótun mátti finna á öllum stigum málsins, utan sem innan hins opinbera kerfis, og á stofnunum í öllum geirum samfélagsins. Баð sem einkenndi athafnafólkið í rannsóknum Kingdons var vilji pess til að verja tíma sínum, kröftum og orðspori (og stundum fjármunum) í von um einhvers konar ávinning í framtíðinni (Kingdon 1995, 122). Раð sem einkenndi stöðu athafnafólksins var að pað gat gert kröfu um áheyrn og par með vænst pess að á pað væri hlustað. Баð hafði pólitísk tengsl eða hæfni til að semja, og pað sem ef til vill var mikilvægast, prautseigju. Рað hafði pá eiginleika að geta bæði talað máli annarra, talað fyrir ákveðnum sjónarmiðum og gert málamiðlanir.

Раð sem getur gert pátt athafnafólks í opinberri stefnumótun áhrifaríkan, að mati Kingdons, er pað svigrúm sem gefst innan stjórnsýslunnar fyrir skapandi hugsun. Athafnafólki er lagið að setja saman með nýjum hætti hugmyndir úr ólíkum áttum (e. recombination) eða finna nýjar leiðir að langpráðum markmiðum. Slíkt svigrúm getur gefist pegar ákveðin óvissa ríkir innan stjórnkerfisins; skipulag ákvarðana einkennist af óljósu eða ruglingslegu verklagi, markmið eru óskýr eða ekki vel framsett (Kingdon 1995, 179-183). Athafnafólki í opinberri stefnumótun er lagið að nýta sér ríkjandi óvissu, en pví getur líka mistekist. Đá getur einnig, eins og fyrr segir, hrein heppni eða tilviljun, jafnvel röð tilviljana ráðið úrslitum (Kingdon 1995; Tuohy 1999).

Styrkur kenningar Kingdons liggur tvímælalaust í pví hvernig hann sér fyrir sér próun hugmynda. Hann lýsir pví hvernig hugmyndir verða að stefnumáli innan stjórnkerfisins og hvernig ákveðnar hugmyndir og tillögur fá hljómgrunn meðal sérfræðinga og stjórnmálamanna. Par liggur rauði práðurinn í leit Kingdons að pví hvernig og hvers vegna sum mál komast á dagskrá stjórnvalda en önnur ekki. Hann beinir sjónum sínum að hugmyndum að baki stefnumáli og hvernig hugmyndunum reiðir af í peirri próun sem pað tekur fyrir hugmynd að verða að veruleika. ๖að eru pessar hugmyndir í nálgun Kingdons sem hafa beint sjónum höfundar að peim pátttakendum í opinberri stefnumótun sem fást við pað að próa hugmyndir og útfæra leiðir til að stefnumörkun stjórnvalda nái fram að ganga. 
Aftur á móti liggur veikleiki Kingdons í peirri takmörkuðu sýn sem kenning hans gefur á starfsemi hagsmunahópa. Pótt honum takist með sannfærandi hætti að lýsa pætti hagsmunahópa og hvað ýmist styrkir eða veikir stöðu hagsmunahópa, pá vantar kjarnan í pví sem drífur hagsmunahópa áfram. Lýsing Kingdons gefur t.d. litla hugmynd um pað hvernig hagsmunahópar starfa, hver hvatinn sé að baki aðkomu peirra, um hvað ágreiningur í málefnum hagsmunahópa snýst í reynd, hvaða aðferðum er beitt og hvernig pær virka. Annar veikleiki í hugmyndum Kingdons er sá að hann setur stjórnmálamenn og hagsmunahópa undir einn og sama hatt í líkani sínu. •að má vissulega færa góð rök fyrir peirri einföldun, en pað gerir greiningu á pví hvað pó aðskilur pessa hópa erfiðari og par með einnig nánari skoðun á peim aðferðum sem beitt er og peim hagsmuna sem eru í húfi.

Í hugmyndir Kingdons vantar betri innsýn í pólitík hagsmunahópa (e. interest group politics). Par vantar meiri skilningi á pví hvernig ágreiningur birtist í dagskrársetningarferli opinberrar stefnumótunar, hvernig tekið er á slíkum ágreiningi og hvaða áhrif pað hefur á niðurstöðuna. Dess vegna er gagnlegt að beita jafnframt hugtökum og skilningi peirra Baumgartner og Jones (1993). Deir hafa beint sjónum sínum að pætti hagsmunahópa sérstaklega og pá einkum peim aðferðum sem peir beita. Kenningu sína hafa peir próað út frá langtímarannsóknum í stefnumótun á vettvangi lýðheilsu og umhverfismála í bandarískum stjórnmálum. Deir hafa á grundvelli peirra rannsókna komið fram með lýsandi en um leið afar mögnuð hugtök sem draga fram með ljóslifandi hætti hvers konar aðferðum hagsmunahópar beita og hvernig pær virka í opinberri stefnumótun. Dannig hafa peir komið fram með hugtakið stefnueinokun (e. policy monpoly). Að peirra mati verður stefnueinokun til vegna pess að til eru stofnanakerfi í sérhverjum málaflokki. Par geta hagsmunahópar komið sér upp aðstöðu (e. policy venue) sem gefur peim formlega stöðu sem felur í sér völd í krafti áhrifa. Áhrifin koma fram í pví að ákveðin sérpekking verður til sem hagsmunahópar geta ráðið yfir og nýtt til pess að móta ímynd málsins (e. policy image) og par með framsetningu sinna mála.

Dannig koma hagsmunahópar sér í pá aðstöðu að skilgreina hvernig hugmyndir peirra eru kynntar. Deir geta ákveðið hvernig um stefnmál peirra er fjallað og hvort tónninn í peirri umræðu er jákvæður eða neikvæður. Petta getur ráðið úrslitum um pað hvort og pá hvernig pær hugmyndir fá athygli. Síðari tíma rannsóknir peirra félaga hafa einmitt beinst að upplýsingum og athygli í opinberri stefnumótun (Jones og Baumgartner 2005; Baumgartner og Jones 2014). Í pessum rannsóknum byggja peir félagar á hugmyndum Herbert Simons um „fjötraða skynsemi“, sem fjallað var um hér að framan. Að pessu leyti eru peir á svipuðum slóðum og Thaler og Sunstein (2009) sem hafa lýst pví hvernig mannshugurinn bregst við áreiti sem fylgir miklu magni upplýsinga. Til að ráða við slíkt áreiti án pess að leggjast í miklar og tímafrekar bollaleggingar pá er gripið til pess að stytta sér leið. Dað er gjarnan gert með aðferðum par sem hættan á hugsana- og staðfestingarskekkjum er mikil. Við pessar aðstæður virka vel pær aðferðir sem miða að pví að fanga athyglina hratt og örugglega, p.e. framsetning málsins (e. framing) (Thaler og Sunstein 2009, 24-41).

Johanna Kuhlmann (2016) hefur reyndar skoðað hvernig pessi hugmynd um „fjötr- 
aða skynsemi“ birtist í líkani Kingdons. Hún hefur komist að pví að í raun byggi Kingdon ekki á pessari hugmynd Simons (1947) eins og maður skyldi ætla miðað við tengsl hugmynda hans við ruslatunnulíkanið, heldur hafi hann aðeins tekið pað hugtak að láni. Kuhlmann skýrir pað pannig að skilningur Simons var sá að stofnanir leitast við að draga úr eða lágmarka áhrif fjötraðrar skynsemi einstaklinga. petta gera stofnanir með pví að auka upplýsingaleit og reyna pannig að draga úr óvissu. Pá hafi, aftur á móti, aukið magn upplýsinga í raun flækt málin enn frekar. Ástæðan er sú að upplýsingar má túlka á marga vegu og pví hafi tilraunir til að draga úr óvissu í raun magnað stig óræðni eða margræðni (e. ambiguity) pegar stefnumarkandi ákvörðun stendur fyrir dyrum. Pannig geri Kingdon ráð fyrir pví að stofnanir stjórnsýslunnar geti gert opinbera stefnumótun flóknari og gefið pannig einstaklingum tækifæri á að höfða til pessara óræðu upplýsinga og túlka mál sér í hag með markvissri framsetningu.

pessi útlegging Kuhlmanns á hugmyndum Kingdons skýrir ef til vill betur á hverju Kingdon byggir pá skoðun sína sem vikið var að í upphafi að inngangi pessarar greinar. Hann lítur svo á að mismunandi skýringar félagsvísindafólks og fjölmiðlafólks á langpráðum árangri í opinberri stefnumótun séu í raun báðar réttar. Gluggi tækifæranna opnast vegna aðstæðna sem eru óháðar athafnafólki í opinberri stefnumótun. Athafnafólk í opinberri stefnumótun kemst hins vegar í aðstöðu til að nýta sér tækifærið sem par gefst m.a. vegna óvissu innan kerfisins.

pessi skilningur á fræðilegum einkennum fyrstu stiga opinberrar stefnumótunar er pað sjónarhorn sem mun leiða umræðu um pá atburðarás sem nú verður lýst hér í öðrum og priðja hluta pessara greinar.

\section{Notendastýrð persónuleg aðstoð: Frá hugmynd til veruleika}

Samhliða formlegu stefnumótunarferli á innan stjórnsýslunnar á vettvangi ríkis og sveitarfélaga um tilfærslu málefna fatlaðs fólk átti sér stað hugmyndafræðileg frampróun á öðrum vettvangi. Pessari próun má m.a. finna stað í starfspjálfun, menntun starfsfólks og rannsóknum á stöðu fatlaðs fólks í samfélaginu. Hagsmunasamtök fatlaðs fólks voru afgerandi og mjög sýnileg í pessari próun. Aukin menntun efldi alpjóðlegt samstarf og pekkingu á stöðu pessa málaflokks í nágrannalöndunum og á alpjóðavettvangi. Með breyttum viðhorfum varð aðgangur að pekkingu um nýjar útfærslur í pjónustu við fatlað fólk útbreiddari og almennari. Verður nú vikið að pessari próun að baki hugmyndinni um notendastýrða persónulega aðstoð.

Notendastýrð persónuleg aðstoð er einn af hornsteinunum í hugmyndafræðinni um sjálfstætt líf fatlaðs fólks. Hugmyndin um sjálfstætt líf fatlaðs fólks tók við af hugmyndinni um eðlilegt líf fatlaðs fólks. Hugmyndin á upphaf sitt í byrjun áttunda áratugarins og má rekja hana til Bandaríkjanna. Hefur hún breiðst paðan um heiminn og mótað alpjóðlega hreyfingu í baráttunni fyrir borgaralegum réttindum fatlaðs fólk. Í hugmyndinni um sjálfstætt líf fatlaðs fólk er krafan um fulla virkni fatlaðs fólks í samfélaginu og tækifæri til að vera við stjórnvölinn í eigin lífi m.a. með sjálfdæmi um pá pjónustu sem parf til að svo megi verða (Vilborg Jóhannsdóttir og Freyja Haraldsdóttir 2010). Í pessu samhengi birtist hugmyndin sem aðgerðarmiðað stefnumál. 
Hugmyndin um aukin áhrif fatlaðs fólks á pað hvaða pjónusta er veitt, hvernig og hvenær var að koma fram með vaxandi punga á Íslandi í byrjun tíunda áratugarins. Pessir straumar komu í upphafi til landsins fyrst og fremst úr norrænu samstarfi og pá einkum frá Danmörku. Par hafði hugmyndin verið útfærð á tilraunastigi i Árósum og beindist hún að pví að koma til móts við réttindi og parfir fatlaðs fólks til að lifa sjálfstæðu lífi. Var leitað leiða til að útfæra hugmyndina í kringum fjögur meginsvið í lífi fatlaðs fólks, atvinnu, frístundir, skóla og heimili.

Á pessu tímabili frá byrjun tíunda áratugarins og fram til ársins 2010 koma fram sterkir og áhrifamiklir talsmenn fatlaðs fólks á Íslandi. Par skipti máli persónuleg reynsla einstakra á meðal fatlaðra og aðstandenda peirra. Pannig varð barátta Ástu Porsteinsdóttur fyrir réttindum fatlaðrar dóttur áberandi í fjölmiðlum og innan málaflokksins og stjórnkerfisins. Sú barátta hefur markað ákveðin tímamót í próun umræðunnar um líf og réttindi fatlaðs fólks á Íslandi og par með hugmyndarinnar um sjálfstæett líf fatlaðs fólks. Í raun má segja að á pessu árum hafi notendahópar fatlaðs fólks verið að taka á sig mynd öflugra hagsmunahópa sem í vaxandi mæli tóku baráttumál fatlaðs fólks í sínar hendur með dyggum stuðningi félagasamtaka peirra.

Auk pess að vera í forystu fyrir Landssamtökin Proskahjálp og fulltrúi samtakanna í norrænu samstarfi, pá var Ásta Dorsteinsdóttir varapingmaður frá 1995 og síðan alpingismaður á árinu 1998. Pannig hafði opinber stefnumótun um sjálfstætt líf fatlaðs fólks fengið ,,andlit“, ekki bara eitthvert andlit, heldur andlit alpingiskonu sem pekkti líf fatlaðs fólks af persónulegri reynslu. Slagorðið um „eitt samfélag fyrir alla“ varð útbreitt í opinberri umræðu.

Hugmyndin um eðlilegt líf fatlaðs fólks hafði upphaflega verið viðfangsefni starfsfólks í pjónustu fatlaðra, einkum fagfólks sem hafði aflað sér proskapjálfamenntunar. Par átti sér stað próun pekkingar á pjónustu við fatlað fólk sem smám saman breytti framkvæmd pjónustunnar frá pví að vera einstaklingsbundin pjónusta í einstaklingamiðaða pjónustu. Lögð var áhersla á að taka mið af pörfum og réttindum hvers einstaklings. Aðlögun pjónustunnar til samræmis við slíka nálgun varð leiðarstefið í baráttu og starfi hagsmunasamtaka fatlaðs fólks og mótaði um leið pær kröfu sem gerðar eru til menntunar og pjálfunar fagfólks. Pannig var nám proskapjálfa elft og fært upp á háskólastig árið 1998. Árið 2003, á Evrópuári fatlaðra, var stofnað til framhaldsnáms í fötlunarfræðum við Háskóla Íslands með samstarfssamningi milli skólans og Félagsmálaráðuneytisins um að ráðuneytið kostaði stöðu lektors til fimm ára (Félagsmálaráðuneytið 2006). Pá var Rannsóknarsetur í fötlunarfræðum sett á laggirnar á árinu 2006 og rannsóknarstofnun í proskapjálfafræðum árið 2010.

Eftir pví sem á leið varð hugmyndin um eðlilegt líf fatlaðs fólks að hugmyndinni um sjálfstætt lífi fatlaðs fólks. Með víðari skírskotun sem opinbert stefnumál náði pessi hugmynd um sjálfstætt líf fatlaðs fólks eyrum sérfræðinga innan stjórnsýslunnar. Að hluta til má ef til vill rekja pað til ársins 1994 pegar gerð var fyrsta tilraun með notendastýrða pjónustu á Íslandi (Heiða Björk Vigfúsdóttir 2009). Pessi tilraun var gerð að frumkvæði páverandi formanns Landsamtakanna Proskahjálp, Ástu Porsteinsdóttur, sem kom pví í kring að Félagsmálaráðuneytið féllst á að gera tilraun með notendastýrða pjónustu við 
dóttur hennar. Pá skipaði páverandi félagsmálaráðherra, Magnús Stefánsson, nefnd til að fjalla um notendastýrða pjónustu. Í drögum Félags- og tryggingamálaráðuneytisins að stefnu í málefnum fatlaðra barna og fullorðinna fyrir 2007-2016 var gert ráð fyrir tilraunum um notendastýrða pjónustu (Félagsmálaráðuneytið 2006). Рað var svo árið 2007 að farið var af stað með tilraunaverkefni á vegum Félagsmálaráðuneytisins fyrir tvo einstaklinga. Í febrúar 2009 fékk Félags- og tryggingamálaráðuneytið Rannsóknarstofnun í barna- og fjölskylduvernd við Háskóla Íslands til að gera könnun með úttekt á pessu tilraunaverkefni. Skýrsla með niðurstöðunum færði ráðuneytinu bæði fræðilega og hagnýta pekkingu á hugmyndinni um notendastýrða pjónustu við fatlað fólk og nánari útfærslum á hugmyndinni. Kom m.a. fram að mikil ánægja ríkti með notendastýrða pjónustuna hjá peim einstaklingum sem höfðu samning og aðstandendum peirra. Aftur á móti pótti ljóst að notendastýrð pjónusta hentaði ekki öllum, t.d. pegar pau skilyrði eru sett að notandinn purfi sjálfur að geta stjórnað pjónustunni (Heiða Björk Vigfúsdóttir 2009).

Alpjóðlegt samstarf hafði áhrif. Slík áhrif urðu ekki aðeins til pess að auka vitund um réttindi og stöðu fatlaðs fólks í samfélaginu, heldur kom slíkt samstarf hreyfingu á opinbera stefnumótun. Á árinu 2007 var t.d. skrifað undir samning Sameinuðu pjóðanna um réttindi fatlaðs fólks. Pá styrkti norrænt samstarf próun pessarar hugmyndar hér á landi með umræðu á norrænum samstarfsvettvangi. Í fyrstunni var sú umræða helst meðal sérfræðinga og fagfólks, en efldist svo stórum með ákveðinni forgangsröðun sem síðar átti sér stað pegar Ísland fór með formennsku í Norrænu ráðherranefndinni 2009-2010. Par varð NPA eitt af pemum nefndarinnar og var pað tækifæri notað til að kortleggja stöðu pessarar hugmyndar á öllum Norðurlöndunum.

Á árinu 2005 kom hingað til lands frá Danmörku, Evald Krogh, á vegum samtaka fatlaðs fólks. Evald Krogh, sem er fatlaður, hefur notið pjónustu í Danmörku sem byggir á hugmyndum NPA. Á ferð sinni til Íslands hitti hann bæði talsmenn úr hópi fatlaðs fólks, embættismenn og stjórnmálamenn. Með persónulega reynslu af pjónustunni og skarpan skilning á útfærslu hugmyndarinnar um NPA náði Evald með sannfæringarkrafti sínum að miðla ákveðinni framtíðarsýn og blása eldmóði inn í samfélag fatlaðs fólks á Íslandi. Heimsóknir Evalds til Íslands áttu mikinn pátt í pví að gera hugmyndina að veruleika t.d. með pví að taka pátt í pví að vinna hugmyndinni brautargengi meðal alpingismanna (Alpingi 2010a).

Vorið 2009 kom Evald Krogh aftur til landsins. Hann og formaður samtaka sjúklinga með MND á Íslandi hófu nokkurra mánaða vinnu sem að mestu fór fram í húsnæði með fundar- og vinnuaðstöðu í Garðabæ. Samstarf peirra félaga var úthugsað og aðgerðarmiðað. Đeir buðu skipulega og kerfisbundið til sín fulltrúum allra flokka á Alpingi til pess að peir gætu kynnt sér hugmyndina um NPA og hvernig hún var útfærð í lífi Evalds og fatlaðs fólks víða í Danmörku. Parna hófst undirbúningur sem síðan leiddi til pess að tillaga til pingsályktunar nr. 16/138 var lögð fram á Alpingi í lok janúar 2010. Flutningsmaður tillögunnar var Guðmundur Steingrímsson sem hafði heillast af hugmyndinni og sem pingmaður tekið málið að sér og gert að sínu í pinginu.

Árið 2008 hafði verið haldin ráðstefna á Íslandi um sjálfstæett líf og í kjölfar ráðstefnunnar eða um ári síðar, pann 17.júní 2009 voru samtökin Samtök um sjálfstatt líf stofnuð 
(Öryrkjabandalag Íslands e.d.). Um svipað leyti var vinnuhópurinn Notendastýrð persónuleg aðstoð að myndast og fékk hópurinn pað verkefni að setja á laggirnar miðstöð sem hefði pað hlutverk að aðstoða notendur sem fengu greiðslu frá ríkinu til að greiða fyrir persónulega aðstoð (Kristín Ólafsdóttir 2015). Í júní 2010 var svo NPA miðstöðin stofnuð (NPA e.d.). Í byrjun árs 2013 var stofnað félag um rekstur miðstöðvar um notendastýrða persónulega aðstoð, NPA miðstöðin svf. (NPA e.d).

\section{Tímamótaákvörðun í pjónustu við fatlað fólk}

\subsection{Aðdragandi breytinga}

Með lögum nr. 47/1979 um aðstoð við proskahefta var hafin uppbygging á úrræðum fyrir fólk með proskahömlun vítt og breytt um landið. Аð margra mati var með lögum pessum stigið eitt stærsta framfaraskref fyrir pennan pjóðfélagshóp sem stigið hefur verið á Íslandi. Landinu var skipt upp í átta pjónustusvæði og var gert ráð fyrir nokkrum áhrifum heimamanna á stjórn og uppbyggingu pjónustunnar í gegnum svokallaðar svæðisstjórnir, pó fjármagn kæmi allt úr ríkissjóði. Með breytingum laga nr. 41/1983 minnkuðu áhrif heimamanna aftur. Á móti kom m.a. að sá markhópur sem lögin tóku til var stækkaður, p.e. lögin tók nú ekki bara til fólks með proskahömlun. Pegar lög nr. 59/1992 um málefni fatlaðra voru sampykkt var sett inn ákvæði í 6. gr. um hlutverk svæðisráða sem áttu pá: „Að hafa frumkvæði að aukinni ábyrgð sveitarfélaga í málefnum fatlaðra”. Hugmyndin með svæðisstjórnunum og síðar svæðisráðunum var að stuðla að aukinni pátttöku hagsmunasamtaka og sveitarfélaga á málaflokkinn.

Árið 1996 sampykkti Alpingi lög nr. 161/1996 með breytingu á gildandi lögum nr. 59/1992 um málefni fatlaðra. Đar var lögfest með ákvæði til bráðabirgða að fela félagsmálaráðherra að undirbúa yfirfærslu málaflokksins frá ríki til sveitarfélaga. Skyldi að pví stefnt að yfirfærsla málaflokksins kæmi til framkvæmda 1. janúar 1999. Í kjölfarið skipaði ráðherra nefndir til pess að undirbúa málið. Afrakstur peirrar vinnu var m.a. ítarlegar upplýsingar um faglega stöðu á pjónustu við fatlað fólk sem og tillögur að mati á kostnaði við pjónustuna og fjármögnun hennar á vegum sveitarfélaga. Prátt fyrir vandaðan undirbúning tókst ekki samkomulag um yfirfærsluna milli ríkis og sveitarfélaga og var verkefnið lagt til hliðar á vordögum árið 2000.

Nokkur hugur var reyndar í mönnum allan tíunda áratug síðustu aldar um að flytja málaflokkinn í heild sinni yfir til sveitarfélaganna. Var m.a. stefna tekin á að færa ákvæði laga um málefni fatlaðra að langmestu leyti inn í lög um félagspjónustu sveitarfélaga. Eftir umtalsverða vinnu og undirbúning var frumvarp pessa efnis lagt fram á Alpingi af páverandi félagsmálaráðherra, Páli Péturssyni, á árinu 2001. Frumvarpið var hins vegar dregið til baka um vorið. Málið strandaði á pessum tíma vegna deilna sem upp komu milli ráðherra og sveitarfélaga um fjármál og afgreiðslu laga um tekjustofna samhliða yfirfærslunni. Pá hafði Öryrkjabandalagið einnig skipt um skoðun í málinu og reyndar byrjað að vara við slíkum flutningi (Landsamtökin Proskahjálp, 2010).

Flutningur á málaflokknum kom aftur til umræðu á árinu 2007. Pá var tekin ákvörðun á samráðsfundi fulltrúa ríkisins og sveitarfélaga 16. febrúar 2007 um að hefja að nýju vinnu við undirbúning að yfirfærslu pessarar pjónustu frá ríki til sveitarfélaga. Frum- 
kvæði að málinu kom að pessu sinni frá fulltrúum Sambands íslenskra sveitarfélaga. Sveitarstjórnarmenn sá í pessari yfirfærslu tækifæri til að ná fram samlegðaráhrifum með annarri pjónustu sem var pegar á höndum, m.a. aksturspjónustu og félagspjónustu. Đá var einnig litið á yfirfærsluna sem leið til að styrkja sveitarstjórnarstigið.

Í framhaldi af fundinum pann 16. febrúar skipaði páverandi félagsmálaráðherra, Magnús Stefánsson, sérstaka verkefnisstjórn í apríl 2007 til pess að stýra vinnunni. Verkefnisstjórnin var skipuð fulltrúum peirra ráðuneyta sem koma að málaflokknum ásamt fulltrúum sveitarfélaganna og heildarsamtaka fatlaðs fólks. Par var sett fram sú hugmynd að yfirfærsla á sérstakri félagspjónustu, sem væri undir lögum um málefni fatlaðs fólks, skyldi vera framtíðarverkefni sveitarfélaga (Félagsmálaráðuneytið 2007a).

Раð var hins vegar ekki fyrr en um tveimur árum seinna að viljayfirlýsing um yfirfærslu málaflokksins var undirrituð. Petta gerðist hinn 13. mars 2009 pegar Ásta R. Jóhannesdóttir, páverandi félags- og tryggingamálaráđherra, Kristján L. Möller, páverandi samgönguráðherra, og Steingrímur J. Sigfússon, páverandi fjármálaráðherra, fyrir hönd ríkisins og peir Halldór Halldórsson og Karl Björnsson, páverandi formaður og framkvæmdastjóri Sambands íslenskra sveitarfélaga, undirrituðu viljayfirlýsingu um að stefna skyldi að flutningi á pjónustu við fatlað fólk til sveitarfélaga um áramótin 2010/2011 (Félagsmálaráðuneytið 2009).

Í viljayfirlýsingunni um yfirfærslu á pjónustu við fatlað fólk frá ríki yfir til sveitarfélaga voru skilgreind markmið yfirfærslunnar. Đar kemur fram að bæta ætti pjónustu og gera hana einstaklingsmiðaðri. Tryggja ætti að eitt stjórnsýslustig bæri ábyrgð á stærstum hluta almennrar félagspjónustu. Dar með yrði samhæfing bætt og dregið úr skörun á ábyrgð milli stjórnsýslustiga. Stuðla ætti að sampættingu nærpjónustu með pví styrkja sveitarstjórnarstigið og einfalda verkaskiptingu milli ríkis og sveitarfélaga. Eftirfarandi verkefni myndu flytjast: sambýli, áfangastaðir, liðveisla, frekari liðveisla, dagpjónusta sem fellur undir vinnumál, hæfing- og endurhæfing, vernduð vinna, heimili fyrir börn, skammtímavistun barna, stuðningsfjölskyldur, félagsleg heimapjónusta, ferðapjónusta fatlaðs fólks, félagsleg ráðgjöf, fjárhagsaðstoð, húsnæðisaðstoð og búsetuúrræði, ráðgjöf og önnur stuðningspjónusta við fatlaða og fjölskyldur peirra. (Félagsmálaráðurneytið, 2009).

\subsection{Breytingar: Skrefið stigið til fulls}

Í lok janúar 2010 gerist pað að pingsályktunartillaga nr. 16/138 um notendastýrða persónulega aðstoð við fatlað fólk var lögð fram á Alpingi. Guðmundur Steingrímsson var fyrsti flutningsmaður tillögunnar, en hún var lögð fram af pingmönnum úr öllum flokkum á pinginu. Aðrir flutningsmenn voru, Sigríður Ingibjörg Ingadóttir pingmaður Samfylkingarinnar, Margrét Tryggvadóttir, pingmaður Hreyfingarinnar, Guðlaugur Dór pórðarson, pingmaður Sjálfstæðisflokks og Puríður Backmann, pingmaður frá Vinstri grænum (Alpingi 2010b). Guðmundur Steingrímsson hafði komið inn sem pingmaður Framsóknarflokksins (Alpingi e.d.) Dingsályktun um notendastýrða persónulega aðstoð við fatlað fólk hljóðar svo: 


\section{STJÓRNMÁL \\ \& \\ STJÓRNSÝSLA}

Alpingi ályktar að fela félags- og tryggingamálaráðherra að koma á fót notendastýrðri persónulegri aðstoð við fatlað fólk á Íslandi með pað að markmiði að fatlað fólk geti almennt notið sjálfstæðis í lífi sínu til jafns við ófatlað fólk. Ráðherra leggi fram tillögu að útfærslu á pjónustunni ásamt frumvarpi til nauðsynlegra lagabreytinga á haustpingi 2010.

Tillagan var sampykkt á Alpingi með öllum greiddum atkvæðum pann 8. júní 2010. Í greinargerð með ályktuninni segir m.a. orðrétt:

Notendastýrð persónuleg aðstoð (NPA) við fatlað fólk hefur rutt sér mjög til rúms á Norðurlöndum og víðar á undanförnum árum, en er komin skammt á veg hér á landi. Notendastýrð persónuleg aðstoð byggist á alpjóðlegri hugmyndafræði sem er í raun einföld og snýst um pað, í stuttu máli, að fatlaðir einstaklingar sem purfa varanlega aðstoð eigi rétt á pví að stjórna lífi sínu sjálfir prátt fyrir pörfina fyrir aðstoð annarra. Réttinn til sjálfstæðis megi tryggja með pví að gefa fötluðu fólki kost á pví að ráða sér aðstoðarfólk sem hjálpi viðkomandi einstaklingum eftir pörfum í daglegu lífi peirra. Hugmyndafræðin gerir pannig ráð fyrir að fatlað fólk stjórni pjónustunni við sig sjálft, í stað pess að piggja pjónustuna inni á stofnunum eða eftir forskrift peirra.

Hugmyndafræðin á sér ríka stoð í samningi Sameinuðu pjóðanna um réttindi fatlaðs fólks, en par segir í 19. gr.: „Ríkin, sem eru aðilar að samningi pessum, viðurkenna jafnan rétt alls fatlaðs fólks til að lifa í samfélaginu og rétt pess til að eiga valkosti til jafns við aðra og skulu gera árangursríkar og viðeigandi ráðstafanir til pess að fatlað fólk megi njóta pessa réttar til fulls og stuðla að fullri pátttöku pess í samfélaginu án aðgreiningar.

Í greinargerðinni kemur fram að stefna í pessum anda hafi verið mörkuð af Félagsmálaráðuneytinu m.a. í yfirgripsmikilli skýrslu, sem gefin var út í mars 2007. Í pessari skýrslu hafði verið fjallað um aðgengi fyrir alla og kynnt metnaðarfull markmiðssetning um pjónustu við fötluð börn og fullorðna til 2016, undir yfirskriftinni „Mótum framtíð““ (Félagsmálaráðuneytið 2007b). Er pessi stefnumótun í samræmi við hugmyndafræðina um sjálfstætt líf og notendastýrða persónulega aðstoð við fatlað fólk.

рá segir ennfremur í greinargerð með ályktuninni:

Í tillögunni er gert ráð fyrir að ráðherra hafi víðan ramma til pessa að leita leiða til pess að koma á pjónustunni. Lagt er til að hann leggi fram tillögur sínar um útfærslur og nauðsynleg lagafrumvörp á haustpingi 2010. Skynsamlegt hlýtur að teljast að ráðherra stofni samráðshóp um verkið par sem í sætu t.d. fulltrúar frá félags- og tryggingamálaráðu- 
neyti og heilbrigðisráðuneyti, ásamt fulltrúum ýmissa samtaka fatlaðs fólks, eins og ÖBÍ, Proskahjálpar, ViVe - virkari velferð, samtaka um sjálfstætt líf, NPA-hópsins og Sjálfsbjargar. Lykilatriði er að fulltrúar notenda komi með sem víðtækustum hætti að mótun pjónustunnar. Einnig má nefna Samband íslenskra sveitarfélaga.

Par segir einnig að tilfærsla málaflokks fatlaðra yfir til sveitarfélaga sé áætluð 1. janúar 2011 og að sú tilfærsla geti einmitt, „skapað hentugan tímapunkt til pess að koma pjónustunni ác“.

Hinn 24. nóvember 2010 var svo lagt fram á Alpingi stjórnarfrumvarp til laga um breytingar á lögum nr. 59/1992 með síðari breytingum. Petta frumvarp varð að lögum nr. 152/2010 um breytingar á lögum um málefni fatlaðs fólks pann 17. desember 2010 sem tóku gildi 1. janúar 2011.

Í IV. kafla laganna í ákvæði til bráðabirgða segir 42. grein:

Sérstöku samstarfsverkefni ríkis, sveitarfélaga og heildarsamtaka fatlaðs fólks skal komið á um innleiðingu notendastýrðrar persónulegrar aðstoðar. Markmið verkefnisins er að próa leiðir til að taka upp notendastýrða persónulega aðstoð við fatlað fólk með markvissum og árangursríkum hætti. Miða skal við að pjónustan verði skipulögð á forsendum notandans og undir verkstjórn hans um leið og hún verði sem heildstæðust milli ólíkra pjónustukerfa.

Ráðherra skal skipa sjö manna verkefnisstjórn til að leiða samstarfsverkefnið um innleiðingu notendastýrðrar persónulegrar aðstoðar. Landssamtökin Droskahjálp og Öryrkjabandalagið skulu tilnefna sinn fulltrúann hvor og Samband íslenskra sveitarfélaga prjá. Ráðherra skipar tvo fulltrúa án tilnefningar og skal annar peirra vera formaður. Varamenn í verkefnisstjórn skulu vera jafnmargir aðalmönnum og skipaðir með sama hætti.

Hlutverk verkefnisstjórnar er að móta ramma um fyrirkomulag notendastýrðrar persónulegrar aðstoðar við fatlað fólk. Í pví skyni munu sveitarfélög í samráði við verkefnisstjórnina leitast við að bjóða fötluðu fólki notendastýrða persónulega pjónustu til reynslu í tiltekinn tíma. Við mat á pví hverjum eða hvaða hópi fatlaðs fólks skuli boðin slík pjónusta skal gæta jafnræðis.

Đá segir að lokum í síðustu málsgrein 42. greinar:

Faglegt og fjárhagslegt mat á samstarfsverkefninu skal fara fram fyrir árslok 2014 en pá skal verkefninu formlega vera lokið. Enn fremur skal ráðherra eigi síðar en í árslok 2014 leggja fram frumvarp til laga par sem lagt verður til að lögfest verði að persónuleg notendastýrð aðstoð verði eitt 
meginform pjónustu við fatlað fólk og skal efni frumvarpsins m.a. taka mið af reynslu af framkvæmd samstarfsverkefnisins.

Frumvarpið var sampykkt samhljóða í pinginu. Eins og fram kemur hér í tilvitnum var stefnt að pví að mat yrði lagt á verkefnið fyrir árslok 2014. Af pví varð ekki og var verkefnið framlengt með lögum nr. 80 frá 2015. Par var ákveðið að slíkt mat skyldi fara fram fyrir árslok 2016, og að ráðherra skyldi eigi síðar en í árslok 2016 leggja fram frumvarp til laga par sem lagt verði til að lögfest verði að persónuleg notendastýrð aðstoð verði eitt meginform pjónustu við fatlað fólk og skal efni frumvarpsins m. a. taka mið af reynslu af framkvæmd samstarfsverkefnisins.

Um meðferð pessarar pingsályktunartillögunnar segir í skjölum pingins frá 2. nóvember 2011:

Samstarfsverkefninu var hleypt af stokkunum í maí sl. Með skipan sjö manna verkefnisstjórnar og hefur stjórnin fundað í níu skipti. Gert er ráð fyrir áfangaskýrslu um framvindu verkefnisins í sept/okt. næstkomandi. Til verkefnisins hafa verið eyrnamerktar 50 m.kr. 2011, 100 m.kr. 2012 og 150 m.kr. 2013. Pessi fjármunir eru vistaðir í innanríkisráðuneytinu. (Alpingi e.d.)

Verkefnisstjórnin hafði verið skipuð frá 14. apríl 2011 til 31. desember 2014. Í lögunum var gert ráð fyrir að ráðherra skyldi skipa sjö manna verkefnisstjórn til að leiða samstarfið um innleiðingu NPA. Landsamtökin Proskahjálp og Öryrkjabandalag Íslands skyldu tilnefna sinn fulltrúann hvor og Samband íslenskra sveitarfélaga prjá fulltrúa. Ráðherra skyldi skipa tvo án tilnefningar og skyldi annar peirra vera formaður. Guðbjartur Hannesson, páverandi velferðarráðherra, skipaði Guðjón Sigurðsson, fulltrúa ViVe - virk velferð samtaka um sjálfstætt líf, í verkefnisstjórnina og Guðmundur Steingrímsson sem formann (Velferðarráðuneytið 2011).

Í gögnum rannsóknarinnar kemur fram að upphaflega hafi staðið til að ráðherra skipaði embættismann í ráðuneytinu sem formann verkefnisstjórnarinnar. Af peirri skipan varð ekki. Tildrög pess að Guðmundur var skipaður formaður eru rakin til aðildar hans að pingsályktunartillögu nr. 16/138 um notendastýrða persónulega aðstoð við fólk með fötlun. Dar hafði hann verið mjög áberandi og eindreginn talsmaður pess að koma NPA hugmyndinni í gegnum pingið og var reyndar fyrsti flutningsmaður tillögunnar á sínum tíma pegar pingsályktunartillagan var lögð fram og sampykkt fyrri hluta árs 2010. Hann hafði talað ákaft fyrir málinu í félags- og tryggingamálanefnd pingsins par sem hann átti sæti frá 2009 til 2011 og einnig eftir að nefndin varð að velferðarnefnd með sameiningu Heilbrigðisráðuneytis og Félags- og tryggingamálaráðuneytis um áramótin 2010-2011. Við undirbúning pingsályktunartilögunnar hafði Guðmundur verið í miklu tengslum við notendahópa og ýmis hagsmunasamtök fatlaðra. Hann hafði orðið pess áskynja að meðal notenda voru hópar sem höfðu af pví áhyggjur að málið myndi mæta fyrirstöðu innan stjórnsýslunnar og tefjast par í meðförum embættismanna. Var talið sýnt að emb- 
ættismenn, bæði hjá ríki og sveitarfélögum, vildu fara af stað með pessa hugmynd af mun meiri varkárni en hópar úr röðum notenda voru tilbúin til að sætta sig við. Er nokkuð víst að fulltrúar úr pessum hópi notenda hafi komið pví til leiðar að velferðarráðherra páverandi, Guðbjartur Hannesson, hafi skipað Guðmund Steingrímsson sem formann verkefnisstjórnar.

Guðmundur hafði verið varapingmaður fyrir Samfylkinguna haustið 2007 og svo aftur í september og október 2008. Hann var hins vegar kjörinn á ping fyrir Framsóknarflokkinn vorið 2009 og var parna vorið 2011 ennpá pingmaður Framsóknarflokksins. Раð var svo snemma á haustdögum 2011 að hann sagði sig úr Framsóknarflokknum og var pingmaður utan flokka fram að kosningum vorið 2013 (Alpingi e.d).

Eins og fyrr segir var skipan sjö manna verkefnisstjórnar ákveðin í lögunum. Aftur á móti var pað gert að tillögu formannsins, Guðmundar Steingrímssonar, að skipa áheyrnarfulltrúa úr röðun notenda. Koma hann pví til leiðar að Freyja Haraldsdóttir, páverandi framkvæmdastjóri NPA miðstöðvarinnar, var skipuð áheyrnarfulltrúi. Đað mæltist misvel fyrir meðal fulltrúa í verkefnisstjórninni. Formaðurinn hafði hins vegar stuðning ráðherrans við pessa tilhögun. Var að peirra mati mikilvægt að fulltrúar notenda kæmu að verkefninu með sem víðtækustum hætti eins og reyndar sagði í greinargerð með pingsályktunartillögunni á sínum tíma. Pegar fulltrúum sveitarfélaganna pótti sem áheyrnarfulltrúinn væri farinn að hafa áhrif á ákvarðanir verkefnisstjórnarinnar, gerðu peir athugasemdir á peirri forsendu að sem framkvæmdastjóri MPA miðstöðvarinnar væri áheyrnarfulltrúinn hagsmunaaðila, sem í rekstrarlegum skilningi hefði beinna fjárhagslegra hagsmuna að gæta af niðurstöðu ákvarðana sem teknar væru af verkefnisstjórninni.

Verkefni verkefnisstjórnar sneru m.a. að nákvæmri útfærslu á framkvæmd NPA með pví að semja handbók um NPA með ítarlegum skilgreiningum fyrir alla hlutaðeigandi aðili um innleiðingu NPA á Ísland (Velferðarráðuneytið 2012a). Af gögnum rannsóknarinnar má sjá að í verkefnisstjórninni var nokkur ágreiningur um skilgreiningar á pví hversu langt skyldi ganga með pessa pjónustu á tilraunarstiginu. Par má ráða að átakalínan innan verkefnisstjórnarinnar var milli formannsins og fulltrúa hagsmunahópanna annars vegar og fulltrúa sveitarfélaganna hins vegar. En ágreiningurinn var lítið eitt flóknari en svo að par hafi fulltrúar hagsmunasamtaka talað einum rómi. Par greindi peim innbyrðis á um hversu langt skyldi ganga í innleiðingu NPA til að byrja með.

Nánar tiltekið pá greindi fulltrúum í verkefnisstjórninni á um pað hversu víðtækur sá hópur ætti að vera sem NPA pjónustan skyldi ná til á pessum fyrstu stigum verkefnisins. Var í pessu sambandi gerður greinarmunur á „notendastýrðri“, „talsmannastýrðri“ og „foreldra-/fjölskyldustýrðri aðstoð“. Мeð notendastýrðri aðstoð er átt við að notandinn sjálfur er verkstjórnandinn og tekur ákvarðanir um við hvað, hvernig og hvenær hann parfnast aðstoðar aðstoðarmanns. Talsmannastýrð er aðstoðin pegar notandinn getur ekki tekið ákvarðanir í eigin málum sjálfur og parf aðstoð og verstjórn annars aðila til að geta nýtt sér NPA samning. Foreldra- eða fjölskyldustýrð aðstoð er pegar foreldri eða annar fjölskyldumeðlimur tekur að sér ákvarðanir og verkstjórn fyrir notanda NPA pjónustunnar. Um pað var deilt hvort NPA ætti á pessu stigi að taka til afmarkaðs hóps og pá í pessu tilviki vera notendastýrð aðstoð eða hvort NPA ætti að ná til allra pessara hópa. 
Peir fulltrúar sem parna áttu sæti í verkefisstjórninni voru fulltrúar fyrir afar ólíka hópa fatlaðs fólks. Landssamtökin Droskahjálp litu einkum til proskahamlaðra, meðan Öryrkjabandalagið leit til hóps geðfatlaðra. Fulltrúi ViVe, formaður MND-samtakanna á Íslandi, Guðjón Sigurðsson, sem var í raun einn aðalhvatamaður pess að hugmyndin um NPA var komin svona langt, talaði hins vegar fyrir prengri skilgreiningu á verkefninu meðan pað væri á tilraunastigi. Áheyrnarfulltrúinn, fulltrúi NPA miðstöðvarinnar, Freyja Haraldsdóttir, var aftur á móti ákafur talsmaður fyrir skilgreiningunni í sinni víðustu merkingu. Раð gerði formaður verkefnisstjórnarinnar einnig og gerði pau sjónarmið að niðurstöðu verkefnisstjórnarinnar. Fulltrúar sveitarfélaganna litu sérstaklega til pess að peim pótti fjármagn til verkefnisins vera takmarkað. Peir höfðu ekki áttað sig á umfangi pessarar pjónustu pegar umræðan um yfirfærsluna hófst að pessu sinni. Pótti peim sýnt að ef farið yrði af stað með svo víða skilgreiningu pá væri með pví verið að senda sveitarfélögunum pann kaleik að purfa að forgangsraða pjónustunni.

Nokkuð var tekist á um tillögu formannsins og áttu forsvarsmenn Samband íslenskra sveitarfélaga m.a. fundi með ráðherra. Úr varð að gefnar voru út leiðbeinandi reglur á vegum ráðuneytisins fyrir sveitarfélögin um innleiðingu NPA og segir par m.a. að „Enda pótt lög um málefni fatlaðs fólks geri skýrlega ráð fyrir NPA sem pjónustuformi er ekki lögskylt að sveitarfélög bjóði slíka pjónustu. Sveitarfélög eiga pví val um pað hvort pau taka pátt í verkefninu á innleiðingartímanum sem reiknað er með að standi til loka árs 2014” (Velferðarráðuneytið 2012b). Fulltrúar sveitarfélaganna féllust að endingu á niðurstöðu verkefnisstjórnarinnar um innleiðingu NPA á Íslandi. Í fyrsta lagi vegna pess að petta var tilraunaverkefni og nota mætti tilraunatímabilið til að gera nákvæmari útreikninga á kostnaði sem fylgdi pessu pjónustuformi. Í öðru lagi vegna pess að sveitarfélögum var ekki skylt samkvæmt lögum að taka pátt í verkefninu. Pá var sveitarstjórnarmönnum umhugað um að yfirfærslan tækist í pessari atrennu og vildu ekki láta stranda á NPA verkefninu.

\section{Umræða}

Með lýsingu á atburðarásinni og á próun hugmyndarinnar um NPA hér að framan má greina helstu pátttakendur í aðdraganda pess að ákvörðun var tekin um að innleiða NPA á Íslandi. Par má fyrst greina hugmyndafræðilega en um leið aðgerðarmiðaða próun meðal notenda og hagsmunasamtaka peirra sem sóttu sér efnivið og styrk til háskólasamfélagsins. Dá má sjá hvernig sérfræðingar innan stjórnsýslunnar taka við sér einkum undir áhrifum úr alpjóðlegu samstarfi. Рað má vissulega einnig skýra með pví að á vettvangi stjórnmálanna var pað opinber stefna að vinna að aukinni dreifstýringu m.a. með pví að flytja verkefni til sveitarfélaganna og par með styrkja sveitarstjórnarstigið. Meðal stjórnmálamanna var pví jarðvegur fyrir nýjar hugmyndir í pessum málaflokki sem einmitt hafði staðið til að flytja til sveitarfélaganna. Hvernig og hvers vegna pað gerðist að stjórnmálin tóku pessa tilteknu hugmynd upp á arma sína á pessum tíma er sú spurning sem hér verður leitað svara við. Í peirri leit er stuðst við hugmyndir dagskrárkenninga í peim tilgangi að laða fram fræðilega umræðu, p.e. nokkurs konar samtal milli rannsóknargagnanna og hugmyndanna par sem pess er freistað að varpa nýju ljósi á pessa atburðarás. 
Pegar hugmyndum dagskrárkenninga er brugðið á pessa framvindu má draga upp mynd af pví sem helst einkennir petta stefnumótunarferli. Hér er tímasetning, einn lykilpáttur í útskýringaraðferðum dagskrárkenninga, mikilvæg.

pegar peir atburðir gerst í kjölfar hrunsins 2008 pá skipast veður í lofti stjórnmálanna. Pær aðstæður skapast sem hér má kalla opnun á glugga tækifæranna í heimi stjórnmálanna. Sá gluggi opnaðist í pessu tiltekna máli við pað að hafin er ný tilraun til að flytja málefni fatlaðra til sveitarfélaganna með viljayfirlýsingu sem undirrituð var í mars 2009. Pá gerist tvennt sem getur haft úrslitaáhrif fyrir hugmynd sem lengi hefur verið í leit að leið til veruleika. Раð er í fyrsta lagi, að málaflokkurinn skiptir um lögsögu. Á slíkum tímamótum gefst oftast tækifæri til að koma að hugmyndum sem við nýjar aðstæður hafa fengið á sig pólitískt fýsilegri mynd. Í öðru lagi, pegar glugginn opnast í heimi stjórnmálanna, pá opnast hann gjarnan út í pað landslag sem umlykur og einkennir hugmyndina pá stundina. Рað er hér sem takturinn í gangverki pessara ólíku strauma hans Kingdons náðu saman. Pessi áfangi náðist pó ekki fyrr en framsetning hugmyndarinnar um NPA hér á Íslandi hafði, eftir margra ára baráttu hagsmunasamtaka fatlaðra, færst frá pví að vera umræða í heimi sérfræðinga á vettvangi stjórnsýslunnar og háskólasamfélagsins til hóps notenda sem hafði tekið á sig mynd aðgerðarsinna. Sem aðgerðarsinnar tókst peim með liðstyrk eigin hagsmunasamtaka og alpjóðlegra tengsla að ná athygli alpingismanna strax á árinu 2009.

Við skoðun rannsóknargagna hefur athyglin fyrst og fremst beinst að peim pátttakendum sem Kingdon hefur komið fyrir í stjórnmálastraumnum, p.e. hagsmunahópum og stjórnmálamönnum. Sérfræðingar innan stjórnsýslunnar eru í hans huga hluti af pessum sama straumi. Pótt bæði sérfræðingar innan stjórnsýslunnar og hagsmunahópar hafi tengingu inn í háskóla- og rannsóknarsamfélagið í stefnustraumnum pá hefur Kingdon, í rannsóknarlegum tilgangi, komið pessum pátttakendum í ferlinu fyrir í stjórnmálastraumnum. Раð skýrist að hluta til af pví að innan stjórnmálastraumsins beita pátttakendur öðrum aðferðum en innan stefnustraumsins (Kingdon 1995, 159). Peir fyrrnefndu semja og gera málamiðlanir sem eru ekki alltaf mjög sýnilegar, á meðan peir síðarnefndu beita fyrst og fram rökleiðslum og sannfæringarkrafti.

Eins og fyrr segir pá hefur Kingdon sett stjórnmálamenn og hagsmunahópa undir einn og sama hatt, p.e. stjórnmálastrauminn. Til pess að sjá hvað í raun og veru hafði gerst í próun NPA hugmyndarinnar á Íslandi inni í pessu straumi Kingdons er mikilvægt, til hægðarauka, að aðgreina pessa tvo hópa í peim tilgangi að geta greint hvað á endanum sameinar pá í pessu ferli og hvenær.

Í fyrsta lagi, pá hafði átt sér stað próun meðal notenda pjónustunnar sem stuðlaði að umbreytingu á skipulagðri starfsemi peirra, virkni og par með áhrifum. Notendahópurinn bar ekki lengur einkenni óvirkra móttakenda eða piggjenda opinberrar pjónustu. Dvert á móti hafði hann tekið á sig mynd öflugs hagsmunahóps sem beitti aðferðum aðgerðarsinna til að ná eyrum stjórnmálamanna. Sem slíkur hafði hann treyst stöðu sína með ákveðnu tungutaki („lingói“), hugtökum og slagorðum sem skilgreindu hvernig málefni fatlaðs fólks skyldu rædd (Baumgartner og Jones 1993). Með alpjóðlegum „liðsauka“ frá Norðurlöndunum einkum Danmörku og síðar skírskotun til aðildar Íslands að 
samningi Sameinuðu pjóðanna árið 2007 var hér að mótast og verða til ákveðin aðstaða (e. policy venue). Бessi aðstaða ljáði notendum og hagsmunasamtökum peirra rödd sem var ekki aðeins með formlega aðkomu að opinberri stefnumótun í eigin málum heldur var hún pess megnug að leggja línurnar í orðræðunni um málefni fatlaðs fólks. Pannig mátti greina hvernig ímynd málsins sem stefnumáls var mótuð (e. policy image). Má sjá í peirri próun merki pess sem einkennir fyrirbærið stefnueinokun (e. policy monopoly) einmitt með slagorðunum „ekkert um okkur án okkar“. Í pessu samhengi er erfitt að sjá hvaða stjórnmálamaður getur ekki verið sammála hugmyndinni um „eitt samfélag fyrir alla".

Í öðru lagi pá kemur fram hvað stjórnmálin áhrærði, að nokkuð annað andrúmsloft hafi ríkt í pinginu eftir hrunið 2008. Margir nýjir og óreyndir pingmenn höfðu komið inn á pingið við óvenjulegar aðstæður í kosningunum um vorið 2009. Sumir voru í leit að hlutverki til að treysta erindi sitt í pinginu á pessum umbrota- og óvissutímum. Á fyrstu árunum eftir hrunið áttu mannúðar- og réttlætismálin greiðan aðgang að eyrum stjórnmálamanna og mál af peim toga áttu pví á vissan hátt leik í heimi stjórnmálanna. pá gætti peirra skoðunar meðal nýrra pingmanna að pingið hefði búið við ákveðið ofríki af hálfu framkvæmdavaldsins. Við pessar aðstæður höfðu pingmannamál greiðari aðgang en verið hafði fyrir hrun og er pingsályktun nr. 16/138 um notendastýrða persónulega aðstoð sem sampykkt var í pinginu í júní 2010 dæmi um pað. Pá höfðu margir meðal nýju pingmannanna pær hugmyndir að pessi skil pyrfti að skerpa og pá að efla hlutverk og aðkomu pingsins að verkefnum framkvæmdavaldsins. Pá kom fram í pessari rannsókn ákveðin tortryggni í garð embættismanna og sérfræðinga stjórnsýslunnar. Par náðu saman ákveðinn hópur stjórnmálamanna og hagsmunahópa í einhvers konar samstöðu gegn kerfi sem pótti vera bæði svifaseint og ógagnsætt. Ljóst var að pað viðhorf sem parna ríkti bar með sér ákveðna óvissu sem átti eftir að gera mörkin milli hlutverka pingsins og hlutverka framkvæmdavaldsins í pessum málaflokki óljósari.

Á vordögum 2011 er Guðmundur skipaður formaður verkefnisstjórnar sem átti að leiða samstarfsverkefni ríkis, sveitarfélaga og heildarsamtaka fatlaðs fólks. Parna er pingmaður kominn hinum megin veggjar í tvennum skilningi. Í fyrsta lagi er parna pingmaður stjórnarandstöðunnar farinn að veita verkefnum meirihlutans forystu og par með að vinna með honum að innleiðingu verkefna. Í öðru lagi er parna pingmaður, fulltrúi löggjafarvaldsins, að vinna með ráðherra í ríkisstjórn að innleiðingu verkefna á vegum framkvæmdavaldsins. Guðmundur hafði átt sæti í félags- og tryggingamálanefnd pingsins frá 2009 og síðan í velferðarnefnd pingsins eftir breytinguna um áramótin 2010-2011. Hlutverk pessarar nefndar var m.a. að hafa eftirlit með málefnum á málasviði Félags- og tryggingamálaráðuneytisins og síðar Velferðaráðuneytisins. Guðmundur var parna sem alpingismaður og nefndarmaður í velferðarnefnd pingsins að hafa eftirlit með sjálfum sér í hlutverki formanns verkefnisstjórnar sem bar ábyrgð á framkvæmd laga um innleiðingu NPA á Íslandi. Dessi staða Guðmundar virtist hvorki vefjast fyrir stjórnmálamönnum né peim sem næstir peim stóðu, ef marka má gögn pessarar rannsóknar.

Guðmundur Steingrímsson hafði verið kosinn á ping vorið 2009 fyrir Framsóknarflokkinn. Hann hafði verið varapingmaður fyrir Samfylkinguna kjörtímabilið par á und- 
an. Um haustið 2011 sagði Guðmundur sig úr Framsóknarflokknum og var pá orðinn pingmaður utan flokka í pinginu. Vorið 2013 hafði nýtt framboð verið stofnað, Björt framtíð, og kom Guðmundur Steingrímsson inn á ping sem 7. pingmaður suðvestur kjördæmis fyrir pennan nýja flokk. Par er varapingmaður Guðmundar, Freyja Haraldsdóttir, sem verið hafði einn aðalhvatamaður og stofnandi NPA miðstöðvarinnar vorið 2010. Guðmundur hafði, sem formaður verkefnisstjórnar um innleiðingu NPA á Íslandi, komið pví til leiðar að Freyja yrði skipuð áheyrnarfulltrúi í verkefnisstjórninni.

Hugmyndir tala ekki fyrir sig sjálfar. ๖аð parf talsmann eða talsmenn til að koma hugmyndum á framfæri og tala fyrir ágæti peirra af nægilegum sannfæringarkrafti. Hér eru tækifærin fyrir áhrif einstaklinga. Eins og Kingdon segir, og nánar er lýst hér að framan, pá parf einstakling sem getur gert tilkall til pess að fá áheyrn; einstakling sem er tilbúinn til að verja kröftum sínum, tíma og orðspori til að tala fyrir tillögu; einstakling sem hefur pólitísk tengsl eða hæfni til að semja. ๖аð parf einstakling sem er í peirri aðtöðu að geta nýtt sér tækifæri sem gefst. Рað tækifæri kann að verða til óháð honum sjálfum. Röð tilviljana kann að eiga hlut að máli, eða hrein og klár heppni.

Eftir á að hyggja geta slíkar tilviljanir tekið á sig rökrétta mynd. Ferill Guðmundar Steingrímssonar, alpingismanns, frá vinnu- og kynningarfundum í Garðabænum á árinu 2009, til pingsályktunartillögu í byrjun árs 2010, til formennsku í verkefnisstjórninni snemma árs 2011 og framboðs í nýjum stjórnmálaflokki vorið 2013 má sjá sem dæmi um feril athafnamanns í opinberri stefnumótun sem nær árangri. Kingdon gerði pátt slíkra athafnamanna í opinberri stefnumótun að sérstöku umtalsefni (e. policy entrepreneur). Slíkir athafnamenn eru virkir ekki bara vegna pess að peir hafi trú á tiltekinni hugmynd, heldur einnig vegna pess að peir hafa aðstöðu til verja tíma sínum í að koma málinu áfram og sjá sjálfum sér hag í að halda peirri baráttu gangandi. Pannig má segja að Guðmundur hafi verið réttur maður á réttum stað á réttum tíma vegna pess að aðstæður í pinginu og innan stjórnsýslunnar eftir hrunið buðu upp á pað.

Рað má færa fyrir pví rök að petta tækifæri hafi verið honum til framdráttar til skemmri tíma litið, við myndun nýs stjórnmálaflokks og framboðs til kosninganna 2013. एá má einnig færa fyrir pví rök að petta nána samstarf við stjórnmálin hafi gagnast notendum til skemmri tíma, p.e. málið komst í gegn og fluttist með yfirfærslunni til sveitarfélaganna. Aftur á móti, er álitamál hversu gagnlegt samstarfið hefur verið pessum notendum til lengri tíma. Í gögnunum kemur fram að NPA miðstöðin hafi um margt liði fyrir pessi nánu tengsl við stjórnmálin par sem ákveðinnar tortryggni hefur gætt í garð miðstöðvarinnar einkum meðan peir sem virkastir voru í innleiðingarferlinu í upphafi voru par í áhrifastöðu.

Eftir pví sem leið á petta kjörtímabil pá fjaraði undan meirihlutanum í pinginu par sem pingmenn sem tilheyrðu meirihlutanum í pinginu höfðu lýst andstöðu sinni við ríkisstjórnina. Við pessar aðstæður sköpuðust ákveðin pólitísk tækifæri. Má par sjá pátt Guðmundar Steingrímssonar í framvindu NPA hugmyndarinnar og hvernig hún kom til kasta pingsins. Hér höfðu, fræðilega séð, skapast pólitísk tækifæri sem voru margslungin.

Í fyrsta lagi pá gat ríkisstjórn sem hékk með meirihlutann í pinginu á blápræði styrkt stöðu sína með aðstoð Guðmundar. Guðmundur sjálfur fékk parna tækifæri til að fylgja 
eftir pví máli sem hann hafði tekið að sér og unnið í samstarfi við hópa utan pingins. Með pessu gat Guðmundur myndað sér ákveðið „kjörfylgi“ og pví víðari skilgreining á væntanlegum notendahóp sem verkefnisstjórnin lagði upp með pví hugsanlega stærra „kjörfylgi“‘. Hér mætti hins vegar líka líta svo á að krafan um víða skilgreiningu á væntanlegum notendahóp sverji sig að vissu leyti í ætt við athafnastjórnmál (Wilson 1989).

Í öðru lagi má segja að hér hafi skapast tækifæri fyrir pingið sem gat í pessu máli myndað sér breiðan stuðning í samfélaginu. Stefnan um notendastýrða persónulega aðstoð var tiltölulega ódýru verði keypt fyrir ríkið par sem verkefnið myndi nú með yfirfærslu málaflokksins færast til sveitarfélaganna. Par með purftu pingmenn ekki að taka ábyrgð á forgangsröðun sem hugsanlega pyrfti að gera og par með „brostnum vonum notenda“ ef til pess kæmi að forgangsröðun sveitarfélaganna myndi breytast. Pvert á móti, pingmenn gátu haldið peirri ímynd á lofti að vera „góða fólkið“ í pólitíkinni. Hér var hægt að njóta vinsældanna miðlægt meðan gagnrýnin myndi lenda á sveitarfélögunum.

Innleiðing NPA hugmyndarinnar horfði öðruvísi við sveitarfélögunum. Fyrir talsmönnum sveitarfélaganna var NPA verkefnið nýtt verkefni sem ekki hafði verið hluti af málinu í fyrri tilraunum sem gerðar höfðu verið til pess að ná samkomulagi um yfirfærslu. Fulltrúar sveitarfélaganna höfðu ekki bara miklar efasemdir um að NPA verkefninu fylgdi nægilegt fjármagn til að geta fylgt peim hugmyndum eftir sem parna var búið að útfæra, heldur virtust menn par á bæ ekki vera nægilega kunnugir hugmyndinni. Í pessu sambandi má sjá hér ákveðin líkindi milli flutnings grunnskólans og flutning á málefnum fatlaðs fólks til sveitarfélaganna. Hugmyndin um „skóla án aðgreiningar“ var hugmynd sem á sínum tíma hafði ekki verið mikið rædd á vettvangi sveitarfélaganna og pví vantaði sameiginlegan skilning á peirri hugmyndafræði milli stofnanna ríkisins og sveitarfélaganna (Nanna B. Bjarnadóttir og Sigurbjörg Sigurgeirsdóttir 2013).

\section{Niðurstöður og helstu vísbendingar}

Hér að framan hefur verið leitast við að svara peim spurningum hvernig og hvers vegna NPA hugmyndin varð að veruleika á Íslandi árið 2011. Đá hafa í fræðilegri umfjöllun verið dregin fram helstu einkenni pessa stefnumótunarferlis sem hér var skoðað sérstaklega.

Í stuttu máli má af framansögðu vera ljóst að pær breytingar sem orðið höfðu á og í umhverfi fatlaðs fólks á Íslandi höfðu styrkt stöðu fatlaðra sem hagsmunahóps. Fatlað fólk var ekki lengur pögull piggjandi hópur opinberrar pjónustu, heldur hagsmunahópur sem hafði tekið á sig mynd aðgerðarsinna. Notendadrifin og aðgerðamiðuð orðræða minnihlutahópa í samfélaginu, átti greiðari aðgang að alpingismönnum í pví andrúmslofti sem ríkti eftir hrunið 2008. Í pví svigrúmi sem par skapaðist á tímum breytinga og óvissu innan stjórnkerfisins sem utan fólust tækifæri. Detta voru tækifæri fyrir athafnafólk í áhrifastöðum með pólitísk tengsl, getu til að grípa slík tækifæri, og vilja til að taka að sér mál og fylgja peim eftir, - jafnvel með nokkuð óhefðbundnum hætti.

Sveitarfélögin höfðu átt frumkvæðið að yfirfærslunni að pessu sinni. Svo virðist sem hér megi sjá dæmi um pað sem Kingdon hefur bent á, að eitt er að hefja mál og koma 
pví á dagskrá; annað að ráða niðurstöðunni. Pegar fulltrúar sveitarfélaganna skrifuðu undir yfirlýsinguna um yfirfærsluna í mars 2009 var hugmyndin um NPA ekki búin að ná eyrum alpingismanna. Бað var ekki fyrr en eftir undirskrift að sá skriður komst á skipulagðar aðgerðir fatlaðra sem á endanum náði að virkja alpingismenn til aðgerða. Tækifærið til að tengja hugmyndina við yfirfærsluna var innsiglað með pingsályktunartillögunni sem lögð var fyrir pingið í janúar 2010, sampykkt í júní og færð í lög í desember petta saman ár. Á pessum tíma höfðu sveitarstjórnarmenn ekki áttað sig á pví hvað fólst í NPA hugmyndinni sem var í yfirfærslupakkanum.

Margt bendir til pess að innleiðingin á NPA hugmyndinni samhliða yfirfærslu málaflokksins til sveitarfélaganna hafi átt sér stað áður en peir sem parna framseldu ábyrgð annars vegar og peir sem tóku við ábyrgðinni hins vegar höfðu öðlast sameiginlegan skilning á pví um hvað NPA hugmyndin snerist og hvað pyrfti til að markmið hennar næðust. Eigi petta við rök að styðjast, pá má sjá vísbendingar um pað sem kann að geta skipt sköpum fyrir framtíð NPA hugmyndarinnar og framkvæmd hennar hér á Íslandi.

рað er í fyrsta lagi vísbending um eignarhaldsvanda hjá sveitarfélögunum á pessari hugmynd. Баð getur auðveldlega leitt til pess að verkefnið fái ekki pann forgang sem pað parf hjá sveitarfélögunum til að ná tilgangi sínum. Í öđru lagi pá er sá hópur sem pjónustan beinist að ekki eins stór pegar litið er til hvers sveitarfélags og pví ekki eins „pólitískt sexy“ á vettvangi sveitarstjórnarmála eins og reyndin var í stjórnmálunum á landsvísu. Í priðja lagi, pá er sú hætta fyrir hendi að skortur á skuldbindingu meðal sveitarstjórnarmanna við pessa hugmynd og pá stefnu sem hugmyndin stendur fyrir leiði til stefnureks. Рað pýðir að aðilar sem hafa viðskiptalegra hagsmuna að gæta fái svigrúm til að hnika framkvæmdinni í pá átt sem betur pjónar slíkum hagsmunum.

Dá vaknar sú spurning hvort réttindabaráttan í pessu samhengi kunni að setja markmið um jöfnuð og gæði i uppnám. Flutningur málaflokksins og par með hugmyndarinnar um NPA til sveitarfélaganna er mikil áskorun fyrir lítil og fámenn sveitarfélög. Pá verður ekki fram hjá pví litið að NPA hugmyndin og yfirfærslan hafa í sameiningu stuðlað að einkavæðingu pjónustunnar, par sem óbeinum stjórntækjum á borð við ávísanir er beitt. NPA hugmyndin í sjálfu sér felur í sér einkavæðingu par sem notandinn fær fjárveitinguna beint til sín og tekur sjálfur, eða einhver fyrir hans hönd, ákvörðun um hvað er keypt, hvar og hvernig. Að pessu leyti á hugmyndin margt skylt við pjónustusamninga og henni fylgir umtalsverður viðskipta- og samskiptakostnaður vegna sérhæfðrar samningagerðar sem aftur er áskorun bæði fyrir lítil og meðalstór sveitarfélög á landinu.

\section{Aftanmálsgrein}

1 Höfundur pakkar viðmælendum í pessari rannsókn fyrir opinská, skýr og upplýsandi viðtöl. Án peirra hefði pessi rannsókn ekki verið gerleg. Đá vill höfundur pakka ritrýnum fyrir góðar og gagnlegar athugasemdir. Góðir ritrýnar eru ómetanlegir. Peir gera góðar rannsóknir betri og miðlun peirra vandaðri og aðgengilegri fyrir lesendur.

\section{Heimildir}

Alpingi (2010a). Ræða Guðlaugs Pórs Dórðarsonar við síðari umræðu: Sótt á vef Alpingis 13. október 2016 http://www.althingi.is/altext/138/06/r07181505.sgml 


\section{STJÓRNMÁL \& STJÓRNSÝSLA}

Alpingi (2010b). Frumvarp til laga um breytingar á lögum nr. 59/1992 um málefni fatlaðra með síðari breytingum. Pskj. 298 - mál 256. mál. 139. löggjafarping 2010-2011. Sótt í júní 2016 á slóð: http:// www.althingi.is/altext/139/s/0298.html

Alpingi (e.d.). Notendastýrð persónuleg aðstoð við fólk með fötlun. Meðferð og framkvæmd ályktunarinnar, 2.nóvember 2011. Sótt 20.09.2016 á vef Alpingis http://www.althingi.is/thingstorf/thingmalalistar-eftir-thingum/ ferill/?ltg $=138 \& \mathrm{mnr}=354$

Alpingi (e.d). Alpingismannatal. Æviágrip pingmanna. Guðmundur Steingrímsson. Sótt 1. desember $2016 \mathrm{http}: / /$ www.althingi.is/altext/cv/is/?nfaerslunr $=704$

Baumgartner, F. R. og Jones, B. D. (1993). Agendas and Instability in American Politics. Chicago: University of Chicago Press.

Baumgartner, F. R. og Jones, B. D. (2014). The Politics of Information: Problem Definition and the Course of Public Policy in America. Chicago: University of Chicago Press 2015.

Bennett, A. (2008). „Process Tracing: A Bayesian Perspective“, í Janet M. Box-Steffensmeier, Henry E. Brady og David Collier (eds.), The Oxford Handbook of Political Methodology, (702-21). New York: Oxford University Press.

Cohen, M, March. J. og Olsen, J. (1972). „A Garbage Can Model of Organizational Choice”, Administrative Science Quarterly 17(1), 1-25.

Collier, D. (2011). „Understanding Process Tracing.“ Political Science and Politics 44(4), 823-830.

Félagsmálaráðuneytið. (2006). Mótum framtíð: Djónusta við fötluð börn og fullorðna 2007-2016. Framtíðarsýn og stefna. http://www.felagsmalaraduneyti.is/media/thjonusta_f/framtidarsyn.pdf

Félagsmálaráðuneytið (2007a). Verkefnisstjórn um verkefnaflutning milli ríkis og sveitarfélaga. Sótt á vef Velferðarráðuneytisins 13. október 2016 af https://www.velferdarraduneyti.is/frettir/frettatilkynningar/nr/3143

Félagsmálaráðuneytið. (2007b). Mótum framtíð: Djónusta við fötluð börn og fullorơna 2007-2016. Starf nefndar um notendastýrða pjónustu. Áfangaskýrsla, mars 2007. Reykjavík: Félagsmálaráðuneytið.

Félagsmálaráðuneytið (2009). Fréttir, Mikilvægt skref stigið í málefnum fatlaðra: Viljayfirlýsing ríkis og sveitarfélaga um tilfarslu á bjónustu vi fatlada frá ríki yfir til sveitarfélaga. Sótt 12. júní 2016 af https:/ / www. velferdarraduneyti.is/malaflokkar/malefni-fatladra/frettir/nr/4296

Félagsmálaráðuneytið (e.d). Ræður og greinar ráðherra. Ræða Magnúsar Stefánssonar á stofnfundi félags um fötlunarrannsóknir, 5. desember 2006. Sótt 30. nóvember 2016 á slóð Velferðarráðuneytisins https://www.velferdarraduneyti.is/radherra/RaedurMS/nr/2994

Green-Pedersen, Ch. og Walgrave, S. (e.d.) (2014). Agenda Setting, Policies, and Political Systems: A Comparative Approach. Chicago: University of Chicago Press.

Heiða Björk Vigfúsdóttir (2009). Úttekt á notendastýrơi pjönustu. Unnið fyrir félags- og tryggingamálaráðuneytið. Reykjavík: Rannsóknastofnun í barna- og fjölskylduvernd (RBF). Sótt 13.október 2016 á http://www.rbf.is/sites/www.rbf.is/files/uttekt_a_notendastyrdri_thjonustu.pdf

Jones, Bryan, D. og Baumgartner, Frank, R. (2005). The Politics of Attention: How Government Prioritizes Problems, 1-27, 275-289. London: University of Chicago Press.

Kingdon, J.W. (1995). Agendas, Alternatives and Public Policies. N.Y.: Longman.

Knill, Ch. og Tosun, J. (2012). Public Policy: A New Introduction. Basingstoke: Palgrave Macmillan.

Kristín Ólafsdóttir (2015). Eitt samfélag fyrir alla, frá bugmynd til veruleika: Helstu áskoranir vegna yfirfarslu málefna fatlaðs fólks frá rikei til sveitarfélaga. Lokaverkefni til MPA gráðu í opinberri stjórnsýslu við Stjórnmálafræðideild Háskóla Íslands.

Kuhlmann, J. (2016) „Clear enough to be proven wrong? Assessing the influence of the concept of bounded rationality within the multiple-streams framework, í Zohlnhöfer, R. og Friedbert W. Rub (eds.), Decision-making under ambiguity and time constraints: assessing the multiple-streams framework. ECPRStudies in European Political Science. Colchester: ECPR press.

Landsamtökin Proskahjálp. (2010). Tilfarsla sértakrar félagspjónustu við fatlað fólk frá ríki til sveitarfélaga - úffarslur og leidir. Sótt í 13. júní 2016 af https://www.velferdarraduneyti.is/media/utgafa2010/ Throskahjalp_yfirfaersla.pdf 
Lindblom, C. E. (1959). „The Science of Muddling Through“, Public Administration Review, 19, 79-88.

Lindblom, C. E. (1979). „Still muddling, not yet through“, Public Administration Review, 39, 517-26.

Lög nr. 152/2010 um breytingu á lögum nr. 59/1992 um málefni fatlaðra, með síðari breytingum. Sótt á vef Alpingis 13. október 2016 http://www.althingi.is/altext/stjt/2010.152.html

Lög nr.161/1996 um breytingar á lögum um málefni fatlaðra, nr. 59/1992, , sótt á vef Alpingis 13. október 2016, http://www.althingi.is/altext/stjt/1996.161.html.

Lög nr. 80/2015 um breytingu á lögum um aðbúnað, hollustuhætti og öryggi á vinnustöðum, nr. 46/1980, og lög um málefni fatlaðs fólks, nr. 59/1992, með síðari breytingum (aukin vinnuvernd og notendastýrð persónuleg aðstoð). Sótt á vef Alpingis 13.október 2016 http://www.althingi.is/ altext/stjt/2015.080.html

Lög um aðstoð við proskahefta, nr. 47/1979.

Lög um málefni fatlaðra, nr. 41/1983.

Lög um málefni fatlaðra, nr. 59/1992.

Nanna B. Bjarnadóttir og Sigurbjörg Sigurgeirsdóttir (2013). "Hvernig opinber stefna gerist: Stefnurek í málefnum lesblindra á Íslandi 1990-2007”, Stjórnmál og stjórnsýsla 9(1), 53-77. Fræðigreinar. Sótt 4.desember 2016 á http://www.stjornmalogstjornsysla.is/?p=1372.

NPA miðstöðin (e.d.). NPA miðstöðin stofnuð, 18.júní 2010. Sótt 3.desember 2016 á http://www.npa. is/8-frettir-tilkynningar-og-annae-efni/8-npa-miestoeein-stofnue)

NPA miðstöðin (e.d). Sampykktir: Félag um rekstur miðstöðvar um notendastýrða persónulega aðstoð. Sampykkt á aðalfundi NPA miðstöðvar svf. pann 28.maí 2013. Sótt 3.desember 2016 á http://npa. is/npa-midstodin/samtykktir

Pettigrew, Andrew M. (1997). "What is a processual analysis?” Scandinavian Journal of Management. Vol. 13(4), 337-348. London: Elsevier Science.

Simon, H. A. (1947). Administrative Behaviour, $1^{\text {st }}$ edn. London: Macmillan.

Thaler, Richard, H. og Sunstein Cass, R. (2009). Nudge: Improving Decisions About health, wealth and happiness. London: Penguin Books.

Tuohy, C. H. (1999). Accidental Logics: The Dynamics of Change in the Health Care Arena in the United States, Britain, and Canada, 3-34. New York: Oxford University Press.

Velferðarráðuneytið (2012b). Leiðbeinandi reglur fyrir sveitarfélög um innleiðingu notendastýrðrar persónulegrar aðstoðar. Júní 2012. Sótt á 3.desember 2016 á https://www.velferdarraduneyti.is/media/npa/Leidbeinandi_reglur_um_NPA_25062012.pdf

Velferðarráðuneytið (2012b). Handbók um NPA. 1.útgáfa 1.febrúar 2012. Sótt 2.desember 2016 á https://www.velferdarraduneyti.is/media/npa/NPA_Handbok_10022012.pdf

Vilborg Jóhannsdóttir og Freyja Haraldsdóttir (2010). Notendastýrð persónuleg aðstoð fyrir fatlad fólk á ÍslandiInnleiding og stjórnsýsla. Í Silja Bára Ómarsdóttir (ritsti.) Djódarspegillinn 2010. Rannsóknir í félagsvísindum XI. Reykjavík: Félagsvísindastofnun Háskóla Íslands. Sótt 13. október 2016 á http:/ / fotlunarfraedi. hi.is/sites/fotlunarfraedi.hi.is/files/Skjol/Freyja_og_Vilborg_grein.pdf

Wilson, J. Q. (1989). Bureaucracy. New York: Basic Books.

Yin, R. K. (1994). Case study research: design and methods. Los Angeles: Sage

Zahariadis, N. (2007). “The multiple stream framework: structure, limitations, prospects”, í P.A. Sabatier (ed.) Theories of the Policy Process, $2^{\text {nd }}$ ed, (pp. 69-92) Boulder, CO: Westview Press.

Zahariadis, N. og Allen, C. S. (1995). "Ideas, networks, and policy streams: privatization in Britain and Germany”, Policy Studies Review 14(1/2), 71-98.

Öryrkjabandalag Íslands (e.d.). Samtök um sjálfstætt líf stofnuð 17. júní. Sótt á vef ÖBí 13. október 2016 http://www.obi.is/is/moya/news/samtok-um-sjalfstaett-lif-stofnud-17-juni 